\title{
Decay in Retinoic Acid Signaling in Varied Models of Alzheimer's Disease and In-Vitro Test of Novel Retinoic Acid Receptor Ligands (RAR-Ms) to Regulate Protective Genes
}

\author{
Thabat Khatib ${ }^{\mathrm{a}}$, David R. Chisholm ${ }^{\mathrm{b}}$, Andrew Whiting ${ }^{\mathrm{b}}$, Bettina Platt ${ }^{\mathrm{a}}$ and Peter McCaffery ${ }^{\mathrm{a}, *}$ \\ ${ }^{a}$ Institute of Medical Sciences, University of Aberdeen, Foresterhill, Aberdeen, Scotland, UK \\ ${ }^{\mathrm{b}}$ Department of Chemistry, Durham University, Science Laboratories, South Road, Durham, UK
}

Accepted 14 November 2019

\begin{abstract}
Retinoic acid has been previously proposed in the treatment of Alzheimer's disease (AD). Here, five transgenic mouse models expressing AD and frontotemporal dementia risk genes (i.e., PLB2 $2_{\mathrm{APP}}, \mathrm{PLB} 2_{\mathrm{TAU}}, \mathrm{PLB} 1_{\text {Double }}, \mathrm{PLB} 1_{\text {Triple }}$, and PLB4) were used to investigate if consistent alterations exist in multiple elements of the retinoic acid signaling pathway in these models. Many steps of the retinoic acid signaling pathway including binding proteins and metabolic enzymes decline, while the previously reported increase in RBP4 was only consistent at late (6 months) but not early (3 month) ages. The retinoic acid receptors were exceptional in their consistent decline in mRNA and protein with transcript decline of retinoic acid receptors $\beta$ and $\gamma$ by 3 months, before significant pathology, suggesting involvement in early stages of disease. Decline in RBP1 transcript may also be an early but not late marker of disease. The decline in the retinoic acid signaling system may therefore be a therapeutic target for $\mathrm{AD}$ and frontotemporal dementia. Thus, novel stable retinoic acid receptor modulators (RAR-Ms) activating multiple genomic and non-genomic pathways were probed for therapeutic control of gene expression in rat primary hippocampal and cortical cultures. RAR-Ms promoted the non-amyloidogenic pathway, repressed lipopolysaccharide induced inflammatory genes and induced genes with neurotrophic action. RAR-Ms had diverse effects on gene expression allowing particular RAR-Ms to be selected for maximal therapeutic effect. Overall the results demonstrated the early decline of retinoic acid signaling in $\mathrm{AD}$ and frontotemporal dementia models and the activity of stable and potent alternatives to retinoic acid as potential therapeutics.
\end{abstract}

Keywords: Aldh1a2, amyloid, chemokines, cholesterol, cyp26a1, cyp26b1, growth factor, Nos2, stra6, Tnf

\section{INTRODUCTION}

Alzheimer's disease (AD) is a chronic multifactorial neurodegenerative disorder that is characterized by the accumulation of amyloid plaques and neurofib-

\footnotetext{
*Correspondence to: Peter McCaffery, Institute of Medical Sciences, University of Aberdeen, Foresterhill, Aberdeen AB25 2ZD, Scotland, UK. Tel.: +44 1224437362; E-mail: p.j.mccaffery@ab dn.ac.uk.
}

rillary tangles, progressive memory impairment, and the deterioration of cognitive ability [1]. It is the most common cause of dementia and contributes to about $60 \%$ to $70 \%$ of all cases [2]. Today, approximately 47 million people have AD worldwide, and the number is expected to reach more than 131 million by 2050 [3].

Retinoic acid (RA), the active metabolite of vita$\min \mathrm{A}$, is well studied from its role in development of 
the central nervous system (CNS), but more recently evidence has accumulated on the importance of RA signaling in the adult CNS [4]. The components of the RA signaling system are present in the adult brain such as the synthetic and catabolic enzymes, receptors, and binding proteins, although the distribution pattern differs from the one observed in the embryonic CNS [5]. RA is known to be crucial for several aspects of neuroplasticity within the adult brain. Neuroplasticity is fundamental to the formation of new memories [6], and aspects of neuroplasticity promoted by RA are long-term potentiation/depression (LTP/LTD) [7], neurogenesis [8], homeostatic plasticity [9], and the capacity to form new neurites and neurite extensions [10].

Use of RA for AD is suggested by findings such as low endogenous retinol levels correlating with cognitive decline in the aging human [11] and that RA falls in the aging rodent brain [12,13]. Mingaud et al. have shown that age-related downregulation of RA signaling disrupts hippocampal LTP and cellular properties, and that retinol supplementation reverses the effects [13]. Among the first proposal of a link between retinoids and $\mathrm{AD}$, Goodman and Pardee reported a genetic linkage between $\mathrm{AD}$ and RA using the Locus Link database, that showed a large number of genes implicated in AD pathology are located at chromosomal loci together with RA signaling system encoding genes [14]. In addition, several studies reported a decline in RA signaling in various $\mathrm{AD}$ models [15].

As RA supports neuronal survival and neuroplasticity, essential for learning and memory, this decline weakens cognitive function [4]. If decreased RA levels promote $\mathrm{AD}$, it would be anticipated that restoration of levels would be protective and several in vitro studies have indicated that RA reduces amyloid- $\beta(A \beta)$ neurotoxicity $[16,17]$. Furthermore, it was shown that a vitamin A-deficient diet in rodents leads to disruption in the RA signaling system and $A \beta$ deposition in the cerebral blood vessels of forebrain neurons, and that these changes were reversed by RA administration [18, 19]. RA also inhibits the production of different cytokines and chemokines, such as interleukin 6 [20, 21], involved in the inflammatory response of many age related diseases. For example, the mRNA levels of interleukin 6 increase early in the hippocampus and cortex of Tg2576 AD model mice [22]. RA also inhibits many aspects of microglia activation, such as tumor necrosis factor alpha production and the expression of inducible nitric oxide synthase [23]. Such anti-inflammatory actions of RA will be beneficial for treatment of neurodegenerative disease.

Boosting the RA signal with synthetic ligands for its receptor improves cognition in transgenic mouse models of $A D$, clearing $A \beta$ in both neurons and microglia as well as providing a strong antiinflammatory action [24]. Hence, synthetic retinoids may provide a treatment for $\mathrm{AD}$ and other neurodegenerative disorders. Tamibarotene (Am80) is an example of a synthetic retinoid that is studied extensively as a candidate drug for AD because of its various beneficial effects. Kawahara et al. reported that administration of Am80 decreased the level of insoluble $\mathrm{A} \beta_{42}$ in APP23 AD model mice [25]. Am80 neuroprotective effects were also observed in inflammation-induced midbrain neurons by increasing brain-derived neurotrophic factor levels [26]. Acitretin is another retinoid drug currently studied. Acitretin was reported to increase the levels of the $\alpha$-secretase (ADAM10) of amyloid- $\beta$ protein precursor (A $\beta P P)$, driving the non-amyloidogenic pathway in neuroblastoma cells with reduction in $A \beta$ levels in APP/PS-1 AD model mice [27]. In addition, Acitretin was reported to cross the blood-brain barrier $(\mathrm{BBB})$ in mice [28]. Endres et al. investigated the changes in $\alpha$-secretase-derived A $\beta P P(A \beta P P s-\alpha)$ levels in the cerebrospinal fluid (CSF) of mild to moderate $\mathrm{AD}$ patients after oral acitretin therapy. Results showed that acitretin increased A $\beta P P s-\alpha$ levels and enhanced non-amyloidogenic A $\beta P P$ processing in human patients [29].

A significant problem with the study of dementia/AD models is that most are only a model of a single hypothesis for the cause of AD. A comprehensive understanding of the disease is necessary to develop successful therapeutics that will tackle the majority of cases. This study used multiple, genetically comparable transgenic knock-in mouse models of $\mathrm{AD}$, and models of tau pathology associated with $\mathrm{AD}$ and frontotemporal dementia (FTD), to investigate alterations in RA signaling at the gene and/or protein level in these models. Hippocampal and cortical mixed primary cultures from Sprague Dawley rats were used as well to perform an initial test of the therapeutic potential of a group of novel synthetic retinoids (RAR-Ms) active with genomic and nongenomic targets [30]. The capacity of these RAR-Ms to beneficially activate or repress $A \beta$ processing genes and anti-inflammatory/neuroprotective genes, in primary neuron/glia cultures suggests retinoids as a line of research of high potential for $\mathrm{AD}$ treatment. 


\section{METHODS}

\section{Retinoid solutions}

All-trans-RA (Sigma-Aldrich) was dissolved at $0.1 \mathrm{M}$ in dimethyl sulfoxide (DMSO) under red light, aliquoted and stored under $\mathrm{N}_{2}$ at $-70^{\circ} \mathrm{C}$, protected from light. Synthetic retinoids (RAR-Ms) were dissolved in DMSO to give $0.01 \mathrm{M}$ stock solutions. RAR-Ms were designed and synthesized as described previously [31-37]. The molecular structures of the RAR-Ms are shown in Fig. 1. The majority of the compounds exhibit high affinity for the RA receptors (RARs).

\section{Transgenic animal models}

Five types of transgenic knock-in mouse models of in-house developed knock-in (PLB) mouse lines were studied to determine if there are any defects in the RA signaling system at the gene and/or protein levels. The
PLB1 $1_{\text {Double }}$ mouse model expresses human mutated APP and Tau (human APP Swedish and London mutations: K670N, M671L and V717I; human Tau mutations: P301L and R406W). PLB 1 Triple expresses human mutated APP, Tau, and PS1 and was created by crossing the PLB $1_{\text {Double }}$ model with an existing presenilin (PS1) mice (A246E) to get the three-gene combination [38]. The two monogenic mouse models APP (PLB2 2 APP) [39] and Tau (PLB2 ${ }_{\text {TAU }}$ ) were created by crossing the double transgenic mouse model PLB1 $1_{\text {Double }}$ with deleter mice (Flp or Cre expressing mice that excise the FRT flanked or floxed regions respectively) [40]. The fifth model, PLB4, expresses human BACE1 [41]. The wild type (WT) control animals $\left(\mathrm{PLB}_{\mathrm{WT}}\right)$ used in the study were generated out of the parental PLB1 $1_{\text {Double }}$, strain, followed by multiple generation crossing with C57BL/6 (Harlan Laboratories Ltd) from human APP and Tau negative littermates. All PLB mice were maintained on the same C57BL/6 background.<smiles>CC1=C(/C=C/C(C)=C/C=C/C(C)=C/C(=O)O)C(C)(C)CCC1</smiles>

all-trans-retinolc acid (RA)<smiles>CC1(C)CCC(C)(C)c2cc(C#Cc3ccc(C(=O)O)cc3F)ccc21</smiles><smiles>CC1(C)CCC(C)(C)c2cc(C#Cc3cc(F)c(C(=O)O)c(F)c3)ccc21</smiles><smiles>CCCCC(C)(C)CCc1ccc(C(=O)O)cc1</smiles><smiles>CC1(C)CCC(C)(C)c2cc(C#Cc3ccc(C(=O)O)c(F)c3)ccc21</smiles><smiles>CC1(C)CCC(C)(C)c2cc(C#Cc3ccc(C(=O)O)cn3)ccc21</smiles><smiles>CC1(C)CCC(C)(C)c2cc(C#Cc3ccc(C(=O)O)nc3)ccc21</smiles><smiles>Cc1sc(-c2ccc(C(=O)O)cc2)nc1-c1cnc2c(n1)C(C)(C)CCC2(C)C</smiles><smiles>Cc1sc(-c2ccc(C(=O)O)c(F)c2)nc1-c1cnc2c(n1)C(C)(C)CCC2(C)C</smiles><smiles>CC(C)(C)OC(C)(C)C</smiles> 
The PLB ${ }_{\mathrm{WT}}$ ( $n=24$ males and 4 females), PLB2 $2_{\mathrm{APP}}(n=5$ males and 1 female), PLB2 2 TAU $(n=8$ males), PLB1 $1_{\text {Double }}(n=7$ males and 5 females), PLB1 1 Triple $(n=5$ males), and PLB4 ( $n=6$ males) mice were killed at 6 months of age by cervical dislocation, while $\mathrm{PLB}_{\mathrm{WT}}$ ( $n=12$ males), PLB2 ${ }_{\mathrm{APP}}(n=4$ males), PLB2 $2_{\mathrm{TAU}}\left(n=12\right.$ males), and PLB1 $1_{\text {Double }}$ ( $n=7$ males) mice were killed at 3 months age. The brains were removed, snap frozen in liquid nitrogen, weighed, and stored in microtubes at $-70^{\circ} \mathrm{C}$ until needed. Each frozen brain was cut along the sagittal plane into two halves and one half was used for ribonucleic acids (RNA) extraction and quantitative polymerase chain reaction (qPCR) analysis work while the other half was used for protein sample preparation and western blotting analysis. Different ratios of males and females were used in the study of different mouse models which might differentially influence the results. There is little published on the influence of gender on RA signaling and so for two different AD models, a wide variety of retinoid signaling genes in the brain were compared between genders. There was no significant difference between males and females (Supplementary Figure 1).

Animals were bred at Charles River UK and delivered to the University of Aberdeen animal facility at least one week before use. All animals were housed and tested in accordance with UK Home Office, the EU directive 63/2010E and the Animal (Scientific Procedures) Act 1986.

\section{Rat primary cultures}

Sprague Dawley (SD) rat pups were used to prepare primary neuron cultures. Rat primary cultures were used because hippocampal neurons are more numerous and faster maturing in rats than mice [42]. The rat pups were killed at postnatal day zero or one (P0-P1) by cervical dislocation and the heads were removed and placed on ice until dissection. The brains were dissected within $1 \mathrm{~h}$ of cervical dislocation.

6-Well plates were coated with $1 \mathrm{ml}$ of polyL-lysine (PLL; Sigma-Aldrich) solution at a final concentration of $0.002 \%$. The plates were incubated for at least $2 \mathrm{~h}$ at $37^{\circ} \mathrm{C}$. Two thorough washes with sterile PBS followed and afterwards the plates were air dried in the cell culture hood and stored at $4{ }^{\circ} \mathrm{C}$ in the fridge wrapped in parafilm until use.

The cortex and hippocampus from rat pup brains were rapidly dissected on a sterile $35 \mathrm{~mm}$ culture dish containing cold serum-free Neurobasal medium (Thermo Fisher Scientific) within $1 \mathrm{~h}$ of the cer- vical dislocation procedure. The collected tissues were placed inside Bijou containers with Neurobasal medium on ice. Following dissection as much Neurobasal medium as possible was removed leaving the tissue at the bottom of the containers. Two $\mathrm{ml}$ of $0.05 \%$ trypsin-EDTA solution (Thermo Fisher Scientific) were then added and the tubes were incubated at $37^{\circ} \mathrm{C}$ for $15 \mathrm{~min}$. The trypsin was then removed and replaced with the same volume of $1 \mathrm{mg} / \mathrm{ml}$ soybeans trypsin inhibitor (Thermo Fisher Scientific) and the container incubated for $5 \mathrm{~min}$ at room temperature. Afterwards, trypsin inhibitor was removed and $3 \mathrm{ml}$ of supplemented Neurobasal medium with 1\% Glutamax (Thermo Fisher Scientific), 2\% B27 without vitamin A (Thermo Fisher Scientific), and $1 \%$ penicillin-streptomycin (Thermo Fisher Scientific) were added above the tissue of each of the tubes. The tissue was gently triturated using a fire polished glass Pasteur pipette and the cloudy medium containing the dissociated cells was passed through a $40 \mu \mathrm{m}$ cell sieve into $50 \mathrm{ml}$ falcon collection tubes. The process was repeated until the tissue was dissociated completely. The cells were then centrifuged at a relative centrifugal force (rcf) of 226 for $4 \mathrm{~min}$ at room temperature using a Mistral 3000i centrifuge (MSE) and resuspended in $2 \mathrm{ml}$ of fresh supplemented Neurobasal medium. Cells were counted using the $\mathrm{TC} 10^{\mathrm{TM}}$ automated cell counter instrument (Bio-Rad) by mixing $15 \mu$ l of $0.4 \%$ trypan blue with $15 \mu \mathrm{l}$ of cell suspension in $0.6 \mathrm{ml}$ microtube and then adding $2 \times 10 \mu \mathrm{l}$ of the mix to the dual chamber cell counting slides (Bio-Rad). After that, 30,000 cells were plated per well and the media was changed every 2 days. The cells were used in experiments after 14 days in vitro (DIV).

\section{Retinoid treatment of primary cultures}

To examine the influence of RA and RAR-Ms on the expression of a group of genes involved in $\mathrm{AD}$, the cells in wells were treated with RAR-Ms for $24 \mathrm{~h}$ in triplicate. $24 \mathrm{~h}$ was chosen as the optimum treatment time from a preliminary study comparing 6 and $24 \mathrm{~h}$ (Supplementary Figure 2). Each experiment was repeated three times. RNA was then extracted from treated cells for qPCR analysis. To examine the influence of RA and other synthetic RAR-Ms on inflammation, the cells were treated first with $1 \mu \mathrm{g} / \mathrm{ml}$ lipopolysaccharide (LPS; Sigma-Aldrich) for $6 \mathrm{~h}$ to induce inflammation followed by RA/RAR-Ms treatment for $24 \mathrm{~h}$. Subsequently, RNA was extracted from the treated cells for qPCR analysis. 
Gene expression analysis

Total RNA was extracted from primary cultures treated with $10 \mathrm{nM}$ RAR-M for $24 \mathrm{~h}$ or frozen half brain tissues of transgenic AD knock-in mouse models using a Qiagen RNeasy mini kit according to the manufacturer's protocol. cDNA was synthesized from $250 \mathrm{ng}$ total RNA from cells or $500 \mathrm{ng}$ total RNA from tissues using High qScript cDNA Synthesis master mix. qPCR reactions using PerfeCTa SYBR Green SuperMix were performed on a Roche LightCycler 480 and analyzed using LightCycler 4801.5 software. Primers were designed using Primer-BLAST [43]. GenNorm primer kits were used for housekeeping genes (PrimerDesign). Standard curves and blank controls were run for all sets of primers tested. A housekeeping gene expression experiment was carried out for each model, and the data obtained were analyzed using the free RefFinder software [44] to determine the best reference genes for each experiment. RNA levels of target genes in PLB models and rat cultures were normalized to the appropriate reference RNA levels according to each experiment and compared to levels in wild type mouse model ( $\mathrm{PLB}_{\mathrm{WT}}$ ) or control untreated cells (CT) which were set at 1. In 6-month-old PLB models experiments, Gapdh and $B 2 m$ reference genes were used with PLB1 $1_{\text {Triple }}$, Nono and Ywhaz were used with PLB2 $2_{\mathrm{APP}}$ and PLB2 ${ }_{\mathrm{TAU}}$, Gapdh and Ywhaz with PLB1 $1_{\text {Double }}$, and Gapdh and Rpl13a with PLB4. In 3month PLB models experiments, Ywhaz and Rpll3a were used with PLB2 $2_{\mathrm{APP}}, \mathrm{PLB} 22_{\mathrm{TAU}}$, and PLB1 $1_{\text {Double }}$. $A c t b$ reference gene was used in rat cultures experiments. The sequence of primers used is shown in Table 1.

\section{Protein analysis}

Frozen half brain tissues of all male transgenic PLB knock-in mouse models (4 PLB ${ }_{\mathrm{WT}}, 5$ PLB2 ${ }_{\mathrm{TAU}}$, and 5 PLB1 $1_{\text {Double }}$ ) were homogenized mechanically in NP-40 lysis buffer containing protease inhibitor cocktail (Sigma-Aldrich, $10 \mu \mathrm{l}$ per $1 \mathrm{mg}$ ) using manual disposable pestles. Protein concentrations were measured using a BCA assay kit (Thermo Fisher Scientific). $30 \mu \mathrm{g}$ protein was loaded and separated by

Table 1

Primer sequences for genes used in qPCR analysis

\begin{tabular}{|c|c|c|c|}
\hline \multirow[b]{2}{*}{ Gene } & \multirow[b]{2}{*}{ Species } & \multicolumn{2}{|c|}{ Primer Sequences } \\
\hline & & Forward Primer $\left(5^{\prime} \longrightarrow 3^{\prime}\right)$ & Reverse Primer $\left(5^{\prime} \longrightarrow 3^{\prime}\right)$ \\
\hline Abca1 & Rat & TGTGGAATCGTCCCTCAGTT & CATCGATGGTCAGCGTGTCA \\
\hline Abcg1 & Rat & GGCCGCTTTCTCGGTCG & TTCAGGTGCCCATTAAGCAGAT \\
\hline Actb & Rat & CCACACCCGCCACCAGTTCG & TACAGCCCGGGGAGCATCGT \\
\hline Apoe & Rat & TCCCCTGCTCAGACCCC & GTCACCTCCAGCTCTCCCT \\
\hline App & Rat & GTTGAGCCTGTCGACGC & AAGCCTGAATCATGTCCGAACT \\
\hline Bace1 & Rat & CCGGCGGGAGTGGTATTATG & CTTGGGCAAACGAAGGTTGG \\
\hline $\mathrm{Ccl5}$ & Rat & CCATATGGCTCGGACACCAC & GCGGTTCCTTCGAGTGACAA \\
\hline $\mathrm{Ccl} 3$ & Rat & TCCTATGGACGGCAAATTCCA & CAGATCTGCCGGTTTCTCTTG \\
\hline Crabp1 & Mouse & GGCGTTGGGTGTGAACGCCA & GGCCAGCTCTCGGGTCCAGT \\
\hline Crabp2 & Mouse & GATGGAGAGCTGATCCTGACAATGAC & TGCTGACCTGGGAGGGGCAA \\
\hline Rbp1 & Mouse & GCAAGTGCATGACCACTGTGAGC & TTCGCTGGCAGAAGCCTGGG \\
\hline Cyp26a1 & Mouse & GCCTGTACCGGGGCGTGAAG & GTGACGTCGCAGCACTGGCT \\
\hline Cyp26b1 & Mouse & CCAGGACTGTATGCCCATGA & CСАCTCACCAACAAAAAGACAAG \\
\hline Ide & Rat & TAGCAGGCCTGAGCTATGATCT & TGGCTGTTTGTCATTGTAACCT \\
\hline Igf1 & Rat & GAAGCGATGGGGAAAATCAGCA & CGAGCTGGTAAAGGTGAGCAA \\
\hline Igf2 & Rat & GGAGGGGAGCTTGTTGACAC & TATGTCTCCAGGAGGGCCAA \\
\hline $\mathrm{Il} 1 \mathrm{~b}$ & Rat & GTGCAAGTGTCTGAAGCAGC & CCCAAGTCAAGGGCTTGGAA \\
\hline Il12a & Rat & GCCTGCTTACCACTGGAACT & CCAAGGCACAGGGTCATCAT \\
\hline Adam 10 & Rat & CAAACGAGCAGTCTCACACG & TGTCCCTCTTCATTCGTAGGT \\
\hline Mme & Rat & TTGCACCGGGGTTCATTTG & TTCTTCGGCTTTGGAGCATTG \\
\hline Nos2 & Rat & GGACTTTTAGAGACGCTTCTGAG & CTCTGAAGAGAAACTTCCAGGGG \\
\hline Aldh1a2 & Mouse & CAAGGAGGCTGGCTTTCCACCC & GGGCTCTTCCCTCCGAGTTCCA \\
\hline Aldh1a3 & Mouse & TCAAAGAGGTCGGGTTCCCTCCG & AGGCGGCTTCTCTGACCAGCT \\
\hline $\operatorname{Rar} \alpha$ & Mouse & CGCCAAGGGAGCTGAACGGG & GGGTGGCTGGGCTGCTTCTG \\
\hline $\operatorname{Rar} \beta$ & Mouse & ACACCACGAATTCCAGCGCTGAC & CAGACCTGTGAAGCCCGGCA \\
\hline Rar $\gamma$ & Mouse & CCTGTGAAGGCTGCAAGGGCT & GTCGGGCGAGCCCTCCTCTT \\
\hline Rbp4 & Mouse & ACGAGTCCGTCTTCTGAGCAACTG & GCACAGCTCCTCCTGCCGTT \\
\hline Sod1 & Rat & AGGATTAACTGAAGGCGAGCA & GGTCTCCAACATGCCTCTCTT \\
\hline Stra6 & Mouse & TTGTGCTTCGGCAGGGCACC & CTGGTCTGCAGCCCCTGGGA \\
\hline Tnf & Rat & GATCGGTCCCAACAAGGAGG & TTTGCTACGACGTGGGCTAC \\
\hline
\end{tabular}


electrophoresis through $12 \%$ SDS-polyacrylamide gels and transferred to nitrocellulose membranes. Western blots were developed using enhanced chemiluminescence (Millipore) and the protein bands were detected and scanned using a myECL Imager (ThermoScientific). The Ponceau S staining was used as a loading control method. The levels of our proteins of interest were normalized to total protein levels rather than using a specific reference protein such as $\beta$-actin [45-49], because the housekeeping protein levels may vary depending on disease state especially in neuropathological events [50]. After normalization, target protein levels were compared to protein levels in wild type mouse models (PLB ${ }_{\mathrm{WT}}$ ) which were set at 1 .

Western blot antibodies used are shown in Table 2.

\section{Statistical analysis}

All data are presented as mean \pm SEM. Samples were run in triplicate and each experiment was also run three times. Statistical analyses were performed in Microsoft Office Excel 2017 or GraphPad Prism 7.0c version (Prism, GraphPad Software, San Diego, CA). Gene expression and western blot data were analyzed by Student's $t$-test or one-way ANOVA with Newman-Keuls multiple comparison test as appropriate; $P$ value $<0.05$ was considered statistically significant. ${ }^{*} \mathrm{p} \leq 0.05,{ }^{* *} \mathrm{p} \leq 0.01,{ }^{* * *} \mathrm{p} \leq 0.001$

\section{RESULTS}

\section{Gene expression of key retinoic acid signaling molecules in Alzheimer's disease mouse models}

The expression of RA signaling system genes was screened first in brains from 6-month-old mice of the five types of transgenic mouse models of AD and FTD

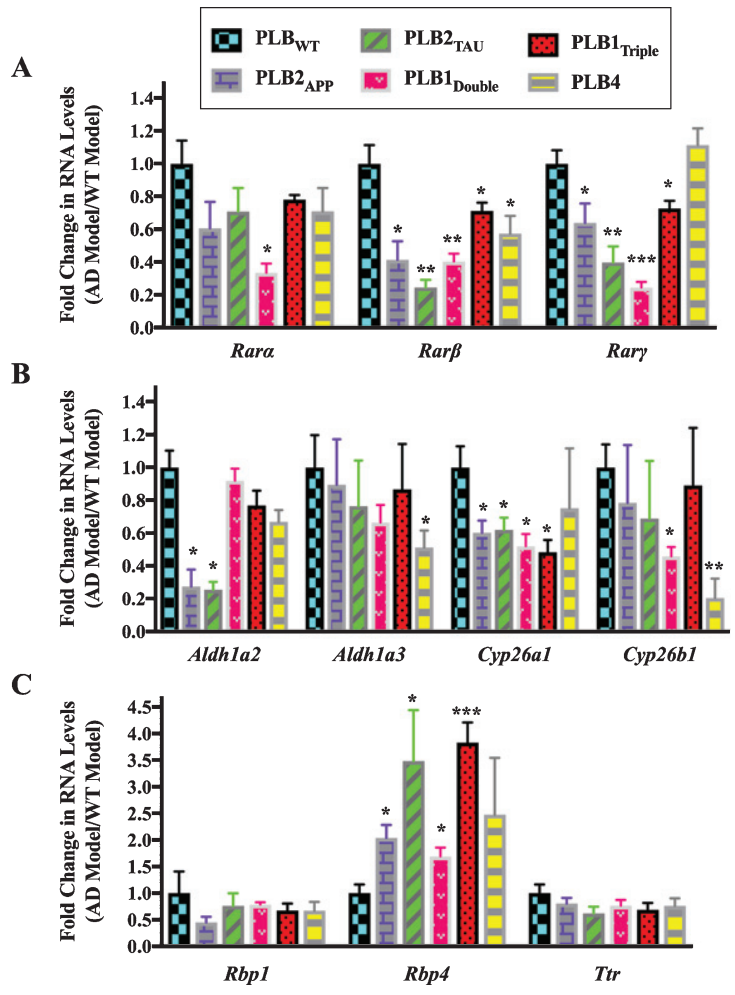

Fig. 2. Gene expression analysis of RA signaling system genes in 6-month-old half brains of different AD and FTD transgenic mouse models. RNA was isolated from half brains of AD and FTD mouse models and analyzed by reverse transcription followed by qPCR. A) RA receptors, B) RA enzymes, and C) retinol binding proteins. RNA levels were standardized with respect to the appropriate reference RNA controls in each model and compared to levels in wild type mouse models (WT) which were set at 1 . Data represent fold change in the mean of RNA levels with $n \geq 6$. Error bars indicate standard error of the mean (SEM) $\left({ }^{*} p \leq 0.5\right.$; ${ }^{* *} p \leq 0.01 ;{ }^{* * *} p \leq 0.001$, one-way ANOVA with Newman-Keuls multiple comparison test).

using a qPCR method to detect RNA levels (Fig. 2). The models used were: PLB2 APP knock-in model that expresses mutations in APP [39], PLB2 $2_{\mathrm{TAU}}$

Table 2

List of antibodies used in western blotting

\begin{tabular}{lcccl}
\hline Primary Antibody & Host & Dilution & $\begin{array}{c}\text { Predicted Molecular } \\
\text { Weight }\end{array}$ & Supplier (CAT\#) \\
\hline CYP26A1 & Rabbit & $1: 200$ & $56 \mathrm{kDa}$ & Source Bioscience (CYP26A11-A) \\
CYP26B1 & Rabbit & $1: 500$ & $58 \mathrm{kDa}$ & Proteintech (21555-1-AP) \\
RALDH1 & Rabbit & $1: 1000$ & $54 \mathrm{kDa}$ & Abcam (ab24343) \\
RALDH2 & Rabbit & $1: 3000$ & $55 \mathrm{kDa}$ & Millipore (ABN420) \\
RALDH3 & Rabbit & $1: 500$ & $53 \mathrm{kDa}$ & Millipore (ABN427) \\
RAR $\alpha$ (C-20) & Rabbit & $1: 1500$ & $51 \mathrm{kDa}$ & Santa Cruz (sc-551) \\
RARß & Rabbit & $1: 500$ & $50 \mathrm{kDa}$ & Abcam (ab53161) \\
RAR $($ C-19) & Rabbit & $1: 200$ & $50 \mathrm{kDa}$ & Santa Cruz (sc-550) \\
RDH10 & Rabbit & $1: 500$ & $39 \mathrm{kDa}$ & Proteintech (14644-1-AP) \\
STRA6 (Q-14) & Goat & $1: 200$ & $74 \mathrm{kDa}$ & Santa Cruz (sc-138065) \\
\hline
\end{tabular}


knock-in model that expresses mutations in Tau [40], PLB1 $1_{\text {Double }}$ knock-in model that expresses mutations in APP and Tau, PLB1 $1_{\text {Triple }}$ knock-in model that expresses mutations in APP, Tau, and presenilin 1 [38], and the PLB4 knock-in model that expresses human BACE1 [41]. The number of PLB mice used for gene expression experiments at 6 months of age was 28 PLB $_{\mathrm{WT}}, 6$ PLB2 $_{\mathrm{APP}}, 8$ PLB2 ${ }_{\mathrm{TAU}}, 12$ PLB1 $1_{\text {Double }}, 5$ PLB1 $1_{\text {Triple }}$, and 6 PLB4.

The data indicated that the RNA levels of 2 subtypes of RARs ( $\beta$ and $\gamma$ ) were downregulated in all PLB models except PLB4 compared to the wild type control mice (Fig. 2A). Rar $\beta$ was downregulated by $60 \%$ in $\mathrm{PLB} 2 \mathrm{APP}(p=0.0413)$ and PLB1 $1_{\text {Double }}(p=0.0056), 80 \%$ in PLB2 $2_{\mathrm{TAU}}$ $(p=0.0013), 30 \%$ in $\mathrm{PLB} 1_{\text {Triple }}(p=0.0419)$, and $40 \%$ in PLB4 $(p=0.0488)$, while Rar $\alpha$ was $66 \%$ downregulated only in the PLB1 $1_{\text {Double model }}$ $(p=0.0451)$. Rary was downregulated in 4 PLB models, with the exception of PLB4, with a decline of $36 \%$ in PLB2 $\mathrm{APP}(p=0.0354), 60 \%$ in PLB2 ${ }_{\mathrm{TAU}}$ $(p=0.0071), 75 \%$ in PLB $1_{\text {Double }}(p=0.0009)$, and $27 \%$ in $\mathrm{PLB} 1_{\text {Triple }}(p=0.0279)$. The expression of RNA levels of two RA synthesizing enzymes (Aldhla2 and Aldhla3) and two RA catabolizing enzymes (Cyp26al and Cyp26b1) was also screened in all PLB models (Fig. 2B). Aldhla2 was downregulated by $74 \%$ in both PLB2 $2_{\mathrm{APP}}(p=0.021)$ and PLB2 $_{\text {TAU }}(p=0.0198)$, while Aldhla3 declined by $50 \%$ in PLB4 ( $p=0.0491)$. Cyp26al was downregulated by $40 \%$ in PLB 2 APP $(p=0.0252)$ and PLB 2 TAU $(p=0.0249)$, and $50 \%$ in PLB1 $1_{\text {Double }}(p=0.0105)$ and PLB1 $1_{\text {Triple }}(p=0.0118)$. Cyp26b1 levels declined by $54 \%$ in PLB $1_{\text {Double }}(p=0.0486)$ and $80 \%$ in PLB 4 $(p=0.0052)$. The expression of three retinol binding protein genes (Crbpl, Rbp4, and Ttr) was then screened in the PLB models (Fig. 2C). Rbp4 RNA was upregulated by $103 \%$ in PLB2 $\mathrm{APP}(p=0.0263)$, $248 \%$ in PLB2 $2_{\mathrm{TAU}}(p=0.0385), 69 \%$ in PLB $1_{\text {Double }}$ $(p=0.0204)$, and $283 \%$ in PLB1 1 Triple $(p=0.0007)$. Rbpl and Ttr RNA levels did not change in the models.

Given the qPCR data confirmed that there were abnormalities in the RA signaling system in AD animal models at 6 months of age, the expression of RA related genes was determined at the earlier age of 3 months in PLB2 $2_{\mathrm{APP}}, \mathrm{PLB} 2_{\mathrm{TAU}}$, and PLB1 $1_{\text {Double }}$ PLB models (Fig. 3). This tests for genetic changes before significant pathology is evident in the brain of these mice $[38,40]$. The number of PLB mice used for gene expression experiments at 3 months of age was 12 $\mathrm{PLB}_{\mathrm{WT}}, 4 \mathrm{PLB} 2_{\mathrm{APP}}, 12 \mathrm{PLB}_{\mathrm{TAU}}$, and 7 PLB $1_{\text {Double }}$.

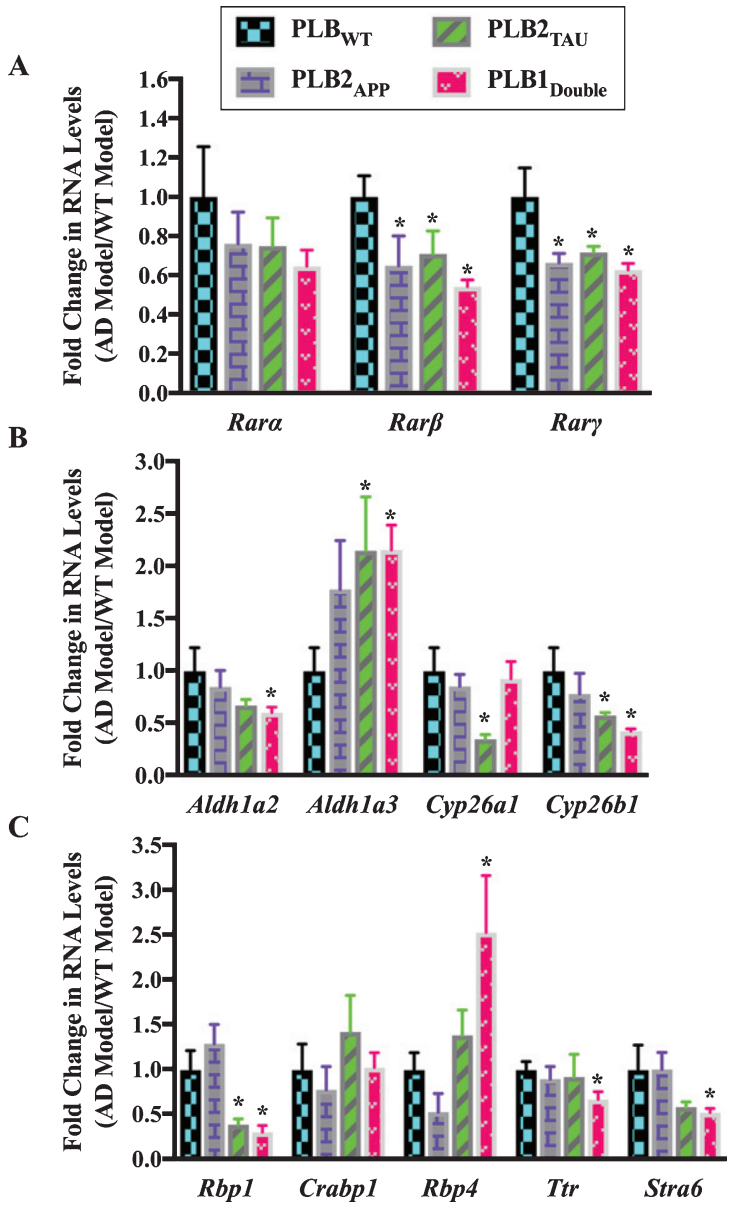

Fig. 3. Gene expression analysis of RA signaling system genes in 3-month-old half brains of different AD and FTD transgenic mouse models. RNA was isolated from half brains of AD mouse models and analyzed by reverse transcription followed by qPCR. A) RA receptors, B) RA enzymes, and C) RA binding proteins. RNA levels were standardized with respect to the appropriate reference RNA controls in each model and compared to levels in wild type mouse models (WT) which were set at 1 . Data represent fold change in the mean of RNA levels of at least six mouse models. Error bars indicate standard error of the mean (SEM) $\left({ }^{*} p \leq 0.5\right.$, one-way ANOVA with Newman-Keuls multiple comparison test).

Analysis of the expression of different RA-related genes indicated that the RA signaling system was also altered in 3-month-old PLB models. The RNA levels of two RAR subtypes ( $\beta$ and $\gamma$ ) showed a pattern of downregulation in almost all PLB models, with approximately $35 \%$ to $40 \%$ decline in $\operatorname{Rar} \beta$ and $\operatorname{Rar} \gamma$ RNA levels (Fig. 3A). Then, RNA levels of Aldh1a2, Aldh1a3, Cyp26al, and Cyp26b1 were screened in PLB models (Fig. 3B). Aldh1a2 was downregulated by $40 \%$ in PLB1 $1_{\text {Double }}(p=0.0339)$. Cyp26al was downregulated by $65 \%$ in PLB2 2 TAU $(p=0.0361)$, while Cyp $26 b 1$ was declined by $42 \%$ and $57 \%$ in 
PLB2 2 TAU $(p=0.0439)$ and PLB1 $1_{\text {Double }}(p=0.0198)$ lines, respectively. Surprisingly Aldhla3 RNA was upregulated by $110 \%$ in both PLB2 $2_{\text {TAU }}(p=0.0495)$ and PLB1 $1_{\text {Double }}(p=0.0108)$. The RNA levels of three retinol binding protein genes ( $R b p l, R b p 4$, and Ttr), a RA binding protein ( Crabpl) gene and a retinol binding protein receptor gene (Stra6) were also screened in the PLB models (Fig. 3C). The RNA level of $R b p 4$ was increased by $150 \%$ in PLB $1_{\text {Double }}$ $(p=0.0478)$ mice. Stra6 RNA did not change in the PLB2 2 APP model, but it was apparently downregulated in the PLB2 $2_{\text {TAU }}(40 \%)$ and PLB1 $1_{\text {Double }}(50 \%)$ models, with a significant decrease evident in the latter $(p=0.0468)$. Ttr decreased by $33 \%$ in PLB $1_{\text {Double }}$ $(p=0.0348)$. Crabpl RNA did not change in the PLB models. The Rbpl RNA was downregulated by $60 \%$ in PLB2 ${ }_{\mathrm{TAU}}(p=0.0495)$ and $70 \%$ in PLB1 $1_{\text {Double }}$ $(p=0.0297)$.

In summary, the expression of a group of RA signaling pathway genes was investigated in 6- and 3-month-old transgenic mice to identify deficits in the RA signaling system. Data indicated that the RNA levels of the RA signaling system were abnormally expressed. RARs, in particular $\beta, \gamma$, as well cyp26 enzymes were downregulated. Other genes were more specifically changed, for instance RBP4 RNA levels were upregulated in all tested models at 6 months but did not change at 3 months while RBP1 transcripts decreased only at 3 months.

\section{Protein expression of key retinoic acid signaling} molecules in Alzheimer's disease mouse models

After investigating the RNA levels of genes encoding the RA signaling system, samples were available to determine RA signaling protein levels in 6-monthhalf brains of the PLB2 2 TAU and PLB1 $1_{\text {Double }}$ models using the western blot technique. These two models were focused on as those changing most consistently in transcript levels. The number of PLB mice used for protein expression experiments at 6 months of age was $4 \mathrm{PLB}_{\mathrm{WT}}, 5 \mathrm{PLB} 2_{\mathrm{TAU}}$, and $5 \mathrm{PLB}_{\text {Double }}$.

The three subtypes of $\operatorname{RAR}(\alpha, \beta, \gamma)$ were downregulated in all $\mathrm{AD}$ mice models compared to the wild type control mice (Fig. 4A). RAR $\alpha$ was downregulated by $17 \%$ and $30 \%$ in PLB2 $2_{\mathrm{TAU}}(p=0.013)$ and PLB1 $1_{\text {Double lines }}(p=0.0037)$, respectively. RAR $\beta$ was only downregulated by $40 \%$ in the PLB1 $1_{\text {Double }}$ model $(p=0.0288)$. RAR $\gamma$ levels were reduced in PLB2 $2_{\mathrm{TAU}}$ by $36 \%(p=0.0484)$. The protein levels of several of the RA synthesizing/degrading enzymes along with RBP4 receptor STRA6 were also screened in the PLB models (Fig. 4B). RDH10 (retinol dehydrogenase enzyme for synthesizing retinal from retinol) did not change in PLB models. RALDH2 and STRA6 proteins were upregulated in some PLB models, with the former being increased by $200 \%$ in PLB1 $1_{\text {Double }}(p=0.0002)$ and the latter by $157 \%$ in PLB2 2 TAU $(p=0.0186)$.
A)

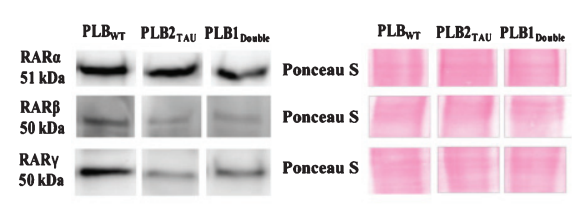

B)

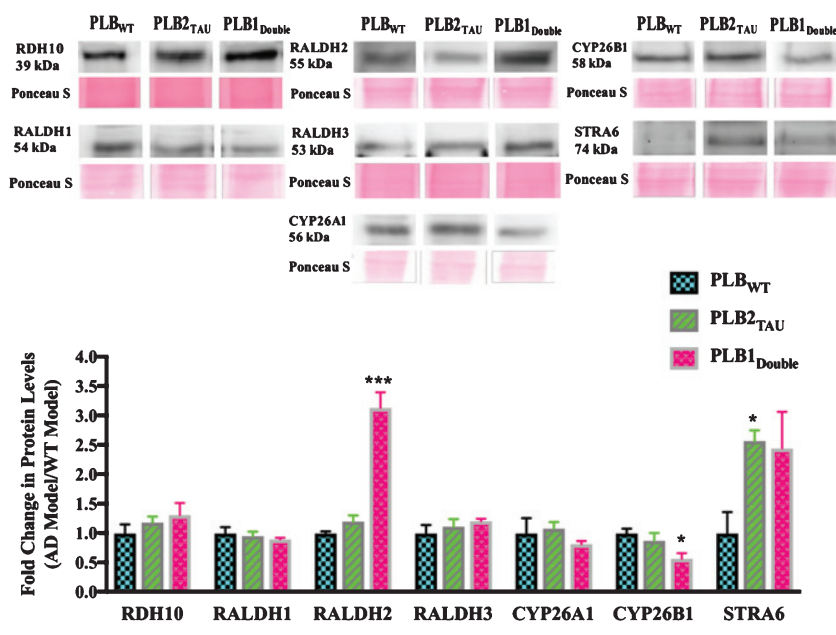

Fig. 4. Western blot analysis of RA signaling system proteins in 6-month-half brains of different AD and FTD transgenic mouse models. $50 \mu \mathrm{g}$ proteins from half brains tissue lysate of PLB mouse models were analyzed by western blot for A) RA receptors or B) RA enzymes and STRA6 proteins and quantified using ImageJ software. Proteins of interest were normalized to total proteins levels measured using Ponceau S staining and compared to protein levels in wild type mouse models (WT) which were set at 1. Shown are mean values of at least four mouse models. Error bars indicate standard error of the mean (SEM) $\left({ }^{*} p \leq 0.5 ;{ }^{* *} p \leq 0.01 ;{ }^{* * *} p \leq 0.001\right.$, one-way ANOVA with Newman-Keuls multiple comparison test). 
CYP26B1 was downregulated by $43 \%$ in PLB $1_{\text {Double }}$ $(p=0.0295)$.

In summary, the levels of RA signaling pathway proteins were investigated in 6-month-old transgenic mice to determine if there were any deficits in this system at the protein level. The RARs $(\alpha, \beta, \gamma)$ were the most consistently downregulated, while STRA6 levels were upregulated in all tested models.

\section{Influence of synthetic retinoids on expression of retinoic acid-related $A D$ genes in mixed neural/glial primary cultures}

The decline in RA signaling in varied PLB models supports the concept of this pathway as a target for AD treatment. A new group of ligands for the RARs have been developed called RAR-Ms, initially screened for dual genomic and non-genomic activity [30]. As an initial genomic test of the RAR-Ms to regulate genes in a beneficial way for AD treatment, 17 genes either directly associated with $\mathrm{AD}$, or providing neuroprotection or acting in an anti-inflammatory fashion, were initially tested on rat hippocampal and cortical mixed primary neural/glial cultures. Cultures were treated with a series of RAR-M compounds at $10 \mathrm{nM}$ concentration after $14 \mathrm{DIV}$ for $24 \mathrm{~h}$ and RNA

A) Expression of Amyloid Processing Genes in Cortical Neurons

$$
\begin{array}{ll}
\square \text { CT } & \text { DC540 } \\
\text { m RA } & \text { DC527 } \\
\text { EC23 } & \text { DC526 } \\
\text { D DC525 } & \text { DC528 }
\end{array}
$$

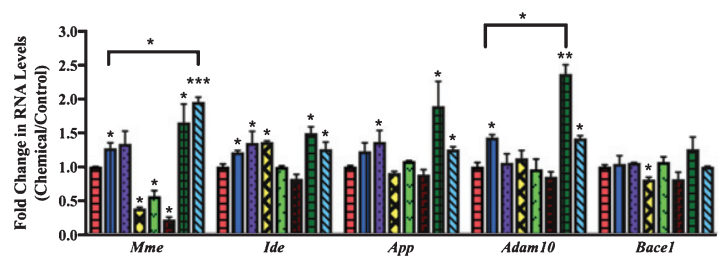

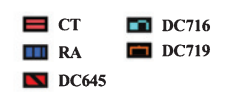

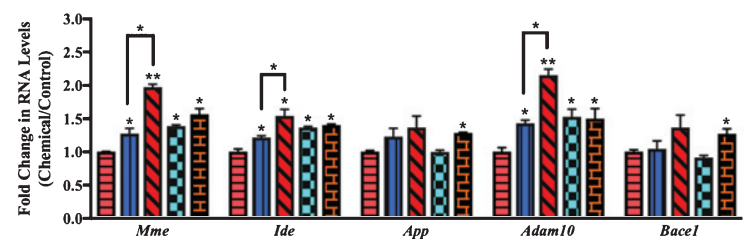

levels were measured by the qPCR technique. For each experiment, 3 wells of 6 -well plate were used per RAR-Ms treatment, and each experiment was repeated three times.

The effect of RAR-Ms on the RNA levels of amyloid processing genes was first examined in cortical and hippocampal mixed primary cultures. The AD related genes examined for RAR-Ms regulation were: Neprilysin (Mme), insulin degrading enzyme (Ide), A disintegrin and metalloproteinase domaincontaining protein 10 (Adam10), amyloid precursor protein $($ App), and $\beta$-site amyloid precursor protein cleaving enzyme 1 (Bacel). These genes were previously reported to be regulated by RA [24, 51-54].

In cortical cultures (Fig. 5A) the RNA levels of the Mme gene were significantly upregulated by DC528 and DC645 compared to both RA and the control, while DC526, DC716, and DC719 increased Mme levels significantly compared to the control only. DC525, DC540, and DC527 significantly downregulated the expression of Mme gene. Ide was upregulated significantly by RA, EC23, DC525, DC526, DC528, DC716, DC719, and DC645. DC645 induction of Ide was significant compared to RA as well. App was significantly upregulated by EC23, DC526, DC528, and DC719. Adam10 was upreg-

B) Expression of Amyloid Processing Genes in Hippocampal Neurons
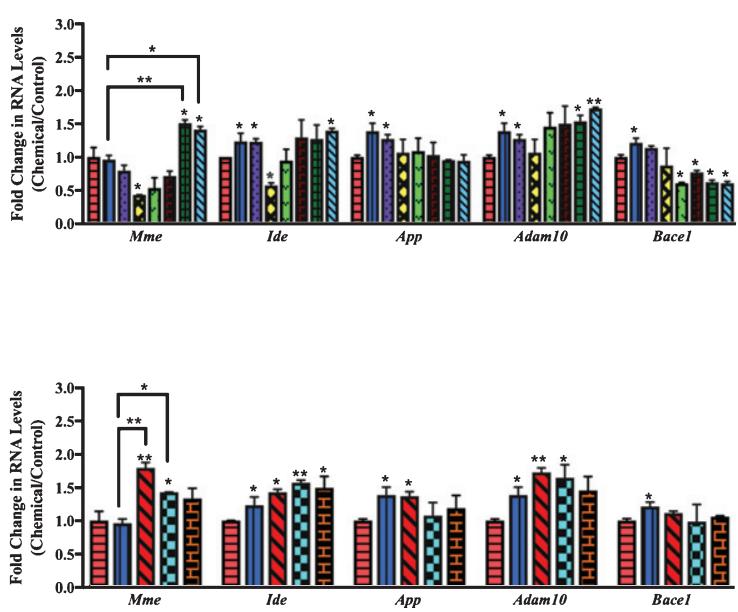

Fig. 5. qPCR analysis of amyloid processing genes in primary hippocampal and cortical cultures treated with RAR-Ms. Primary rat cortical (A) and hippocampal (B) cultures were treated with $10 \mathrm{nM}$ RAR-M for $24 \mathrm{~h}$. RNA was isolated and analyzed by reverse transcription followed by qPCR. Amyloid processing gene RNA levels were standardized with respect to the Actb RNA control and compared to levels in control untreated cells (CT) which were set at 1. Shown are mean values of three biological replicates analyzed in triplicate. Error bars indicate standard error of the mean (SEM) $\left({ }^{*} p \leq 0.05 ;{ }^{* *} p \leq 0.01,{ }^{* * *} p \leq 0.001\right.$, one-way ANOVA with Newman-Keuls multiple comparison test). 
ulated significantly by DC528, DC716, DC719, DC526, and DC645, with the latter two compounds also being significantly greater than RA. Bacel was significantly upregulated by DC719 and downregulated by DC525.

In hippocampal cultures (Fig. 5B), Mme was significantly upregulated by DC526, DC528, DC645, and DC716 with this increase being significant compared to RA and the control. DC525 treatment significantly downregulated Mme levels. Ide was significantly upregulated by EC23, DC528, DC645, DC716, and DC719. DC525 treatment downregulated Ide gene levels. App levels increased significantly with EC23 and DC645 treatments. Adam10 RNA levels increased in EC23, DC526, DC528, DC645, and DC716 significantly. Bace1 was downregulated by DC540, DC527, DC526, and DC528.

In addition, the effect of RAR-Ms on the expression of genes involved in neuroprotection was investigated in rat primary cultures (Fig. 6). The neuroprotection related genes examined for RAR-Ms regulation were: two ATP-binding cassette $(\mathrm{ABC})$ transporters A1 and G1 (Abcal and Abcgl), the Cu$\mathrm{Zn}$ superoxide dismutase ( $\operatorname{Sod} 1)$, and apolipoprotein $\mathrm{E}$ (Apoe). These genes were previously reported to be regulated by RA [55-57].

From analysis of cortical culture data (Fig. 6A) RNA levels of $A b c a l$ were significantly upregulated

A) Expression of Neuroprotection Genes in Cortical Neurons
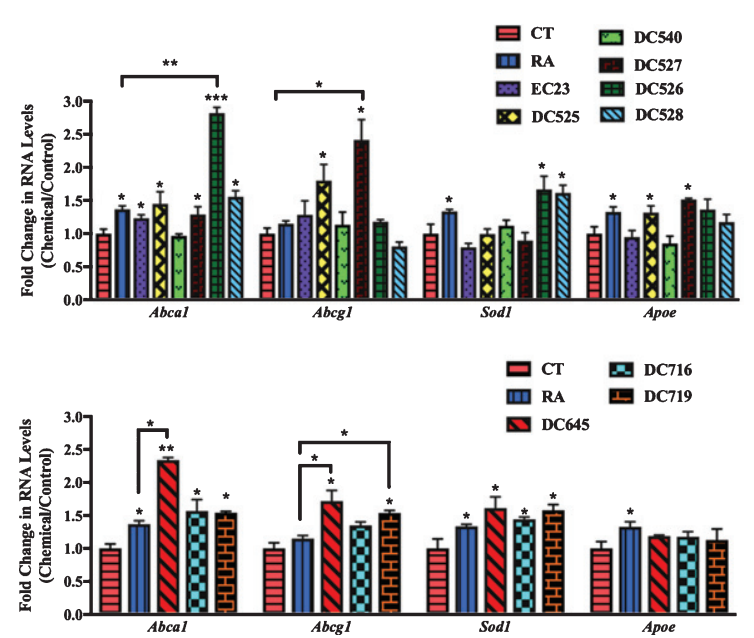

by all RAR-Ms except DC540, while DC526 and DC645 were shown to be more effective than RA. Abcgl was upregulated by DC525, DC527, DC645, and DC719, with the latter three compounds being more efficacious than RA. Sodl gene was induced to a notable extent by DC526, DC528, DC645, DC716, and DC719, and Apoe levels were shown to be increased by treatment with DC525 and DC527 treatments.

In the case of hippocampal cultures (Fig. 6B), Abcal was upregulated by DC526, DC528, DC645, DC716, and DC719 compared to control and RA, while DC527 increased Abcal compared to control only. Abcgl was upregulated significantly by DC526 and DC719 compared to RA and the control. Sodl RNA was induced by all RAR-Ms except EC23. All RAR-Ms treatments induced Apoe, with DC528 exhibiting particularly effective activity compared to both RA and the control.

The effect of the RAR-Ms on the expression of genes involved in neuroinflammation and neuroprotection was then examined in the primary cultures. The inflammation related genes examined for regulation by the RAR-M compounds were: two C-C motif chemokine ligands, number 3 and $5(\mathrm{Ccl} 3$ and $\mathrm{Ccl} 5)$, tumor necrosis factor alpha (Tnf), and inducible nitric oxide synthase (Nos2) as well as two types of interleukins 12 and 1 beta ( $I l-12$ and $I l-1 \beta)$. In addition, two neuroprotective growth factors were examined,
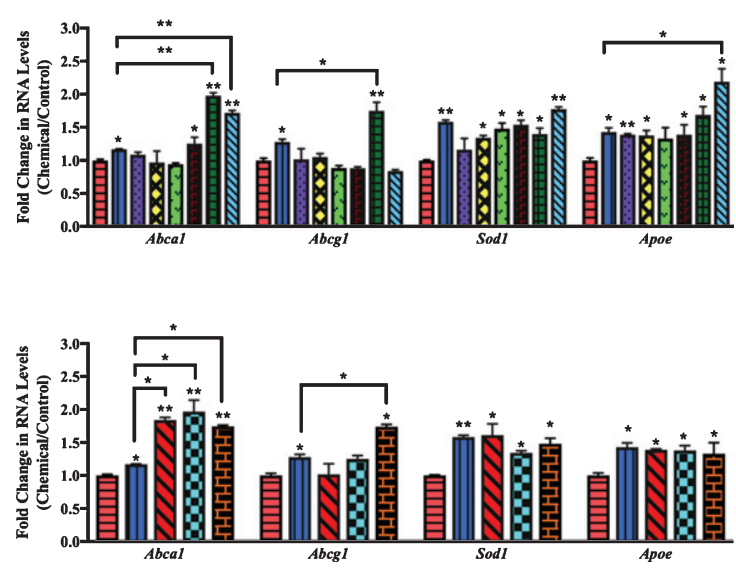

Fig. 6. qPCR analysis of neuroprotection genes in primary hippocampal and cortical cultures treated with RAR-Ms. Primary cortical (A) and hippocampal (B) cultures were treated with $10 \mathrm{nM}$ RAR-M for $24 \mathrm{~h}$. RNA was isolated and analyzed by reverse transcription followed by qPCR. RNA levels were standardized with respect to the Actb control and compared to levels in control untreated cells (CT) which were set at 1 . Neuroprotective genes were upregulated by RAR-M treatment. Shown are mean values of three biological replicates analyzed in triplicate. Error bars indicate standard error of the mean (SEM) $\left({ }^{*} \mathrm{p} \leq 0.05 ;{ }^{* *} \mathrm{p} \leq 0.01,{ }^{* * *} \mathrm{p} \leq 0.001\right.$ one-way ANOVA with Newman-Keuls multiple comparison test). 


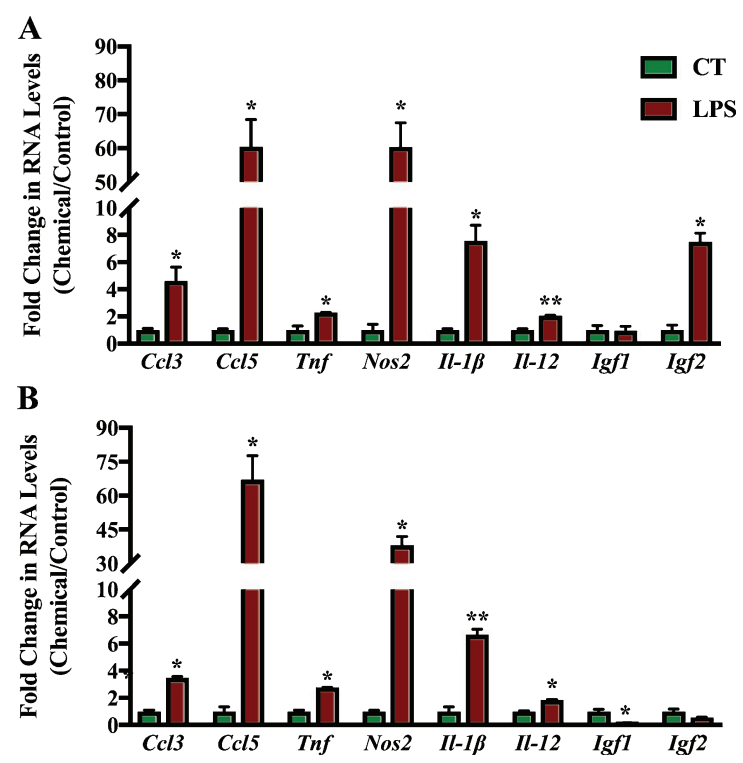

Fig. 7. qPCR analysis of inflammation regulated genes in primary hippocampal and cortical cultures treated with LPS. Primary cortical (A) and hippocampal (B) cultures were treated with $1 \mu \mathrm{g} / \mathrm{ml}$ LPS for $6 \mathrm{~h}$ to induce inflammation. RNA was isolated and analyzed by reverse transcription followed by qPCR. Inflammatory gene expression was standardized with respect to the Actb RNA control and compared to levels in control untreated cells (CT) which were set at 1 . The expression of all genes was upregulated during inflammation except Igf1 which was downregulated significantly in hippocampal cultures. Shown are mean values of three biological replicates analyzed in triplicate. Error bars indicate standard error of the mean (SEM) $\left({ }^{*} \mathrm{p} \leq 0.05 ;{ }^{* *} \mathrm{p} \leq 0.01\right.$, student's $t$-test).

insulin growth factor 1 and 1 ( $I g f 1$ and $I g f 2)$. These genes have all been reported to be regulated by RA previously [23, 58, 59].

Mixed primary neuronal and glial cultures were first treated with $1 \mu \mathrm{g} / \mathrm{ml}$ LPS for $6 \mathrm{~h}$ to induce inflammation (Fig. 7). LPS treatment induced the expression of all inflammation related genes significantly in the cortex cell culture, except for Igfl. In hippocampal cultures, all genes were also upregulated except for $I g f I$ and $I g f 2$. Igfl levels were reduced significantly in hippocampal cultures after LPS treatment. $C c 15$ was the gene induced to the greatest extent during inflammation followed by Nos 2 and $I l-1 \beta$.

After the induction of inflammation, the expression of these inflammation related genes was screened in the primary cultures treated with synthetic RARMs to determine how the expression of these genes changed in response to the RAR-M compounds.

In cortical cultures (Fig. 8), all RAR-Ms decreased the RNA levels of the $\mathrm{Ccl} 3$ gene except EC23. $\mathrm{Ccl} 5$ was downregulated by RA, DC526, DC528, DC645,
DC716, and DC719 significantly. Tnf was downregulated by all RAR-Ms except RA, DC525, and DC716, with DC645 being the most effective. Nos2 RNA levels were downregulated by all RAR-Ms except DC716. Il-1 $\beta$ was notably upregulated by EC23 and, in contrast, downregulated by DC540, DC526, DC528, DC645, DC716, and DC719, with DC526 and DC716 being significantly more effective compared to RA. Il-12 RNA levels were upregulated by all RAR-Ms. Igfl RNA levels were increased significantly by all RAR-Ms except DC527, DC526 and DC719. Treatment with RA, EC23, DC525, DC645, and DC716 caused a significant upregulated in Igf2 gene expression.

In hippocampal cultures (Fig. 9), all RAR-Ms decreased the RNA levels of the Ccl3 gene except EC23 and DC525. Ccl5 was downregulated by all RAR-Ms except DC540 and DC526, with DC527, DC528, and DC645 being significantly more effective compared to RA. Tnf was downregulated by RA, DC719, DC526, DC528, and DC645, with the latter three compounds being more effective than RA. Nos 2 and Il-1 $\beta$ RNA levels were downregulated by RA, DC527, DC526, DC528, DC645, DC716, and DC719. Il-12 and Igfl RNA levels were upregulated by RA, DC526, DC528, DC645, DC716, and DC719. Igf2 was significantly induced by all RAR-Ms except RA, DC540, and DC527, compared to both control and RA.

In summary, novel RAR-Ms were screened for their ability to regulate the expression of 17 genes involved in either amyloid processing, neuroprotection, or neuroinflammation in rat mixed primary cultures. These initial tests of the therapeutic potential of RAR-Ms indicated that different ligands had varied effects on the investigated genes and DC526, DC528, and DC645 were more effective than RA in regulating almost all genes in a therapeutically beneficial way. Other RAR-Ms had beneficial effects, but on a limited number of genes and not all of them such as DC540 and DC527 while RAR-Ms such as DC525 regulated some genes in the opposite direction to most ligands.

\section{DISCUSSION}

It is well recognized that the complex pathology of dementias such as AD means it cannot be adequately studied in a single animal model, as they are largely based on a single hypothesis, and usually rely on rare genetic mutations detected in $\mathrm{AD}$ 

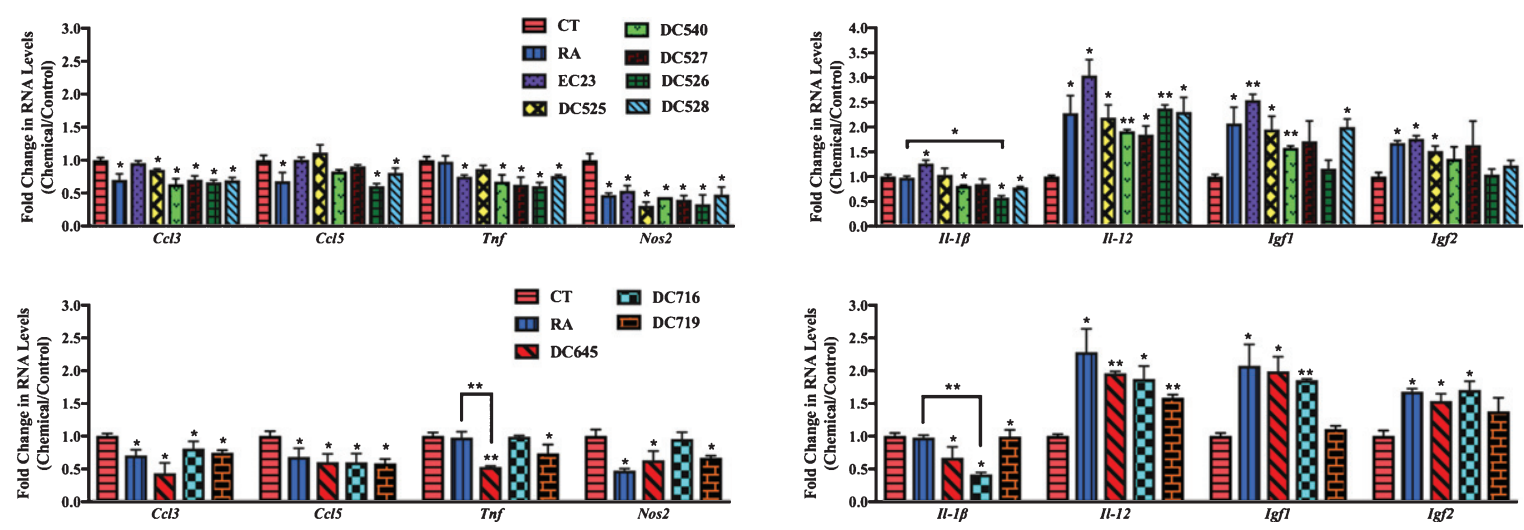

Fig. 8. qPCR analysis of inflammation regulated genes in primary cortical cultures treated with LPS followed by RAR-Ms. Primary cortical cultures were treated with $1 \mu \mathrm{g} / \mathrm{ml}$ LPS for $6 \mathrm{~h}$ to induce inflammation, and then with $10 \mathrm{nM} \mathrm{RAR}-\mathrm{M}$ for $24 \mathrm{~h}$. RNA was isolated and analyzed by reverse transcription followed by qPCR. Inflammatory genes were standardized with respect to the Actb RNA control and compared to levels in control untreated cells (CT) which were set at 1 . The expression of all genes was downregulated after RAR-M treatment except for Il-12, Igf2, and Igf2 which were upregulated. Shown are mean values of three biological replicates analyzed in triplicate. Error bars indicate standard error of the mean (SEM) $\left({ }^{*} \mathrm{p} \leq 0.05 ;{ }^{* *} \mathrm{p} \leq 0.01\right.$, one-way ANOVA with Newman-Keuls multiple comparison test).
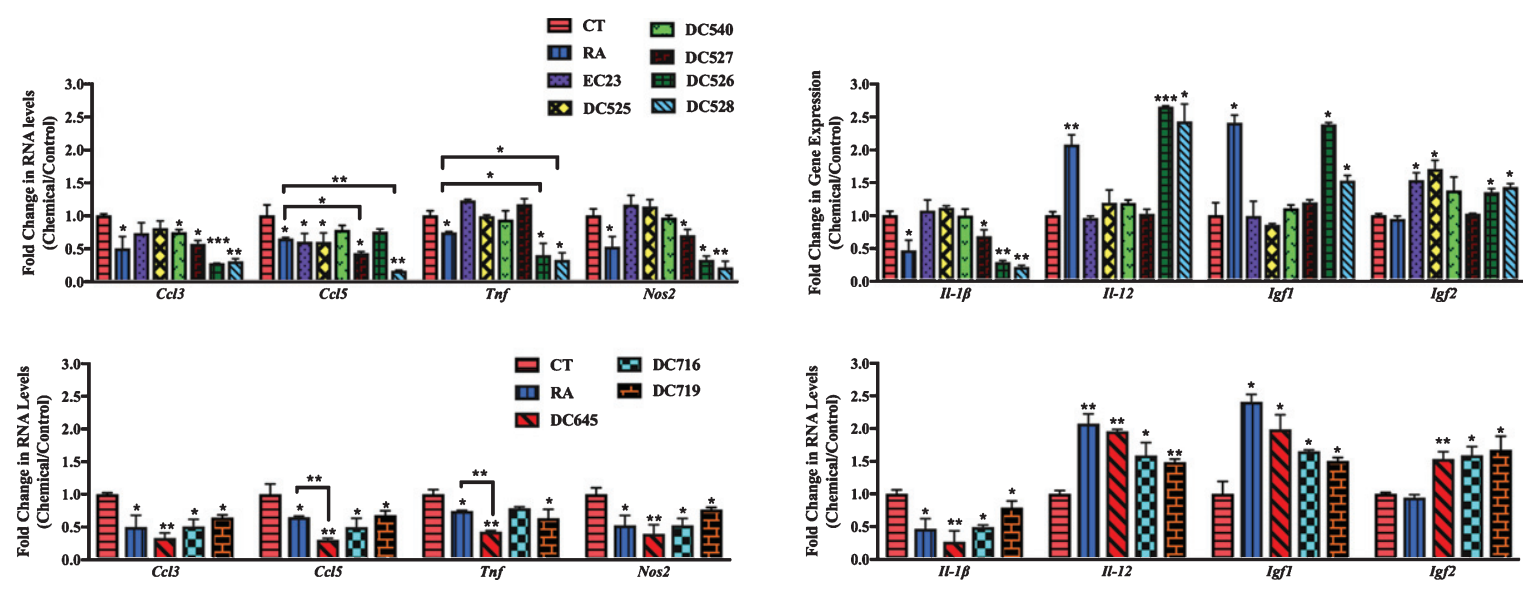

Fig. 9. qPCR analysis of inflammation regulated genes in primary hippocampal cultures treated with LPS and RAR-Ms. Primary hippocampal cultures were treated with $1 \mu \mathrm{g} / \mathrm{ml}$ LPS for $6 \mathrm{~h}$ to induce inflammation, and then with $10 \mathrm{nM} \mathrm{RAR}-\mathrm{M}$ for $24 \mathrm{~h}$. RNA was isolated and analyzed by reverse transcription followed by qPCR. Inflammatory genes were standardized with respect to the Actb RNA control and compared to levels in control untreated cells (CT) which were set at 1 . The expression of all genes was downregulated after RAR-M treatment except Il-12, Igf2, and Igf2 which were upregulated. Shown are mean values of three biological replicates analyzed in triplicate. Error bars indicate standard error of the mean (SEM) $\left({ }^{*} \mathrm{p} \leq 0.05 ;{ }^{* *} \mathrm{p} \leq 0.01 ;{ }^{* * *} \mathrm{p} \leq 0.001\right.$, one-way ANOVA with Newman-Keuls multiple comparison test).

(APP, BACE, presenilin) or FTD (tau) patients. There is also a need to examine the contribution of individual genes versus bi- or trigenic models of $A D$ [60]. Several studies have investigated the changes in retinoid signaling in over-expression models, but none have so far investigated genetically comparable models [61], expressing mutated tau and/or APP as well as BACE1, in knock-in models. It has here been demonstrated that endogenous RA signaling changes differentially in five different transgenic PLB mouse lines, at the gene and/or protein level. Genes encoding components of the RA signaling system were abnormally expressed in these mouse models at 6 months of age. Further, analysis of gene expression in 3-monthold mice illustrated early deficits in RA signaling, such as the reduction of $\operatorname{Rar} \beta$ and $\operatorname{Rar} \gamma$ receptors in all PLB models and the decline in Cyp26b1 and $R b p 1$ in both PLB2 $2_{\mathrm{TAU}}$ and PLB1 $1_{\text {Double }}$ models. This is indicative that such changes may be an initiator event in $\mathrm{AD}$.

The three subtypes of RA receptors $(\alpha, \beta, \gamma)$ were downregulated in the PLB models at both RNA and 
protein levels and this decrease will lead to an almost inevitable fall in the strength of RA signal in the brain. The link between vitamin A and dementia had been made by Corcoran and colleagues who reported that Rar $\alpha$ was downregulated in the forebrain of 6-monthold vitamin A deficient rats accompanied by a loss of choline acetyltransferase (ChAT) and followed by $\mathrm{A} \beta$ deposition in 1-year-old VAD rats [19]. It was also reported that Rar $\beta$ and/or Rxr $\gamma$ null mice exhibit impairment in LTP and working memory [7] and that there is an approximately $30 \%$ decline in $\operatorname{Rar} \beta$ and $\operatorname{Rxr} \beta / \gamma$ expression in the hippocampus of aged mice [62]. Furthermore, pathological samples from AD patients showed Rar $\alpha$ deficits along with $\mathrm{A} \beta$ deposition in the surviving neurons in the meningeal vessels of the neocortex [19]. These results imply that a decline in RA receptors may be among the events initiating $\mathrm{AD}$.

The initial catalyst resulting in an early decrease in expression of the RA receptors is unknown. One possibility is that this is an indicator of an early decline in RA levels in the brain. All RARs are inducible by RA $[63,64]$ and in particular RAR $\alpha$ and $\beta$ in the CNS [19] can decline when RA levels fall. A clue to what triggers the fall in RA may lie in the role microglia have in brain RA metabolism. Activation of microglia increases their capacity to degrade RA [65], possibly part of the inflammatory response to $A D$, while $A \beta$ is able to inhibit RA synthesis, potentially blocking microglia RA synthetic capacity [24]. It is of note that decline in RAR expression and RA signaling is also evident in the aging mouse and that this is reversible by RA treatment [66]. Although the cognitive decline in $\mathrm{AD}$ and normal aging each has its distinguishable features, there is also significant overlap between the two in genetic susceptibility and epigenetic input [67, 68]. Epigenetic modification has been proposed in the treatment of both AD [69] and aging [70]. This may be another mechanism by which RA can influence cognitive decline and aging given the capacity of RA to regulate epigenetic change [71].

Changes in other RA signaling components, enzymes, and binding proteins were more complex in the PLB models suggesting that they may be secondary to the decline in the RA receptors or secondary to other events in the AD brain. The Aldhla2 gene encoding the enzyme that synthesizes RA was downregulated at the RNA level in 6-month-old PLB2 2 APP and PLB2 2 TAU PLB models and 3-month-old PLB1 $1_{\text {Double }}$ PLB model, but surprisingly it was upregulated at the protein level at 6 months. The increase in RALDH2 protein could be a feedback/compensatory mechanism at the translational level in order to increase RA synthesis in response to the decline of RA signal. A similar phenomenon was described in the neuroblastoma cell line LA-N-5, where RALDH was increased when the cells were depleted in RA and was restored to normal levels on addition of RA [72]. It is of particular note that there is a two-fold increase in the RALDH protein in the hippocampus and parietal cortex of $\mathrm{AD}$ patients [72]. Further, an increase in RALDH2 protein was reported in the spinal cord of rats during inflammation [73, 74], and one of the features of $\mathrm{AD}$ is inflammation. This may be a key interacting event leading to the increase of RALDH2 in the $\mathrm{AD}$ mouse models, regulating at a translational level despite the decrease in Aldhla 2 transcript. It has been reported in a number of studies that mRNA and protein expression levels do not always correlate [75, 76] and this is also the case for the retinoid signaling system in the adult brain [77]. Several factors could influence the mRNA-protein correlation such as posttranscriptional and posttranslational modifications, mRNA and protein stability, protein half-life and the lower rate of transcription compared to translation in mammalian cells.

The RA catabolizing enzymes (CYP26A1 and CYP26B1) were both downregulated at the RNA and protein levels in all our PLB models. Both these genes are reliant on RA for induction as a regulatory mechanism to protect against excess RA and their expression falls when RA is low [78-81]. Their decline in the PLB mice may reflect the overall reduction in RA signaling in the AD/FTD brain.

$\mathrm{RBP} 4$ is a liver secreted retinol carrier protein in the circulation [82]. Its function in the brain is unknown but an increase in RBP4 protein levels was reported in the brain of APP/PSEN1 AD model mice [83], and it is upregulated in the liver and forebrain of 8-monthold PLB4 mice [84]. The current study reproduced these findings and $R b p 4$ gene levels were upregulated in the brains of all 6-month-old PLB models but at 3 months only in the PLB1 $1_{\text {Double }}$ mouse line. High levels of RBP4 protein have been found in the amyloid plaques of human AD patients [85]. Particularly intriguing is the correlation of decreasing $\mathrm{RBP} 4$ in the CSF with progression of normal to mild cognitive impairment to $\mathrm{AD}$, suggesting a movement of RBP4 between brain compartments with disease, although this study was with a small patient pool [86]. Changes in RBP4 may be part of the metabolic disorder linked with AD [87] and the inconsistent change between mouse models at 3 months in RBP4 tran- 
script suggests that this may not be an early change in disease.

Alterations in STRA6, the RBP4 cell surface receptor [88], may also be part of these metabolic disruptions in AD. STRA6 changed in a complex fashion, being downregulated at the RNA level but upregulated at the protein level in PLB2 ${ }_{\mathrm{TAU}}$ and PLB1 $1_{\text {Double }}$ AD mouse models (Fig. 4). STRA6 acts as a cell surface signaling receptor activating the JAK2/STAT5 signaling transduction pathway following RBP4/retinol binding which induces the expression of suppressor of cytokine signaling 3 (SOCS3) protein, which in turn inhibits insulin signaling [89]. CRBP1 is part of the STRA6 complex on the intracellular side and assists with transport of retinol into the cell and sites of its use [88], and is also linked to metabolic disorders [90]. Rbpl gene expression levels were downregulated in 3-monthold PLB2 $2_{\mathrm{TAU}}$ and PLB1 $1_{\text {Double }}$ PLB models. Thus, the overexpression of STRA6 along with the upregulated RBP4 levels in the brain and downregulated CRBP1 on the intracellular side of the receptor might jointly interrupt movement of retinol into cells and dysregulate metabolism in AD. Furthermore, TTR, a carrier protein for retinol and thyroxine in the plasma and CSF [91], was decreased in 3-month-old PLB $1_{\text {Double }}$ at the gene level. Lower levels of TTR protein were reported previously in the CSF of AD patients [92].

The animals used are refined $\mathrm{AD}$ models with low expression of AD-related genes and the studies presented here on prodromal stages of disease add to the accumulating evidence that RA signaling declines early in neurodegeneration leading to the proposal of the use of RAR ligands as therapeutics to boost RA signaling [93]. There is currently preliminary pilot data on the use of retinoids in clinical trials, but the potential therapeutic effects of retinoids in $\mathrm{AD}$ are still at an early stage of investigation. For example, the results of the clinical trial of bexarotene (RXR agonist) suggests that it may reduce brain amyloid and increases serum $A \beta_{1-42}$ in ApoE4 noncarriers in mild to moderate AD patients [94]. Moreover, acitretin (RAR agonist) entered Phase II clinical trials in Germany in 2010, and the preliminary results reported 25\% increase in A $\beta P P s-\alpha$ in CSF of mild to moderate AD patients in the treatment group [29].

In this study, we have provided an initial test of a new RAR-M class of retinoid, selected by screening for both genomic and non-genomic activity, the drugs were tested on primary neuron/glia mixed cultures from hippocampus and cortex. The RAR-Ms tested herein are significantly more chemically stable than RA, which can be easily oxidized and isomerized in the presence of light, oxidants, and excessive heat $[95,96]$. The RAR-M family is exemplified by EC23 [33] which has been shown to be 8 -fold greater in potency $\left(\mathrm{EC}_{50}\right)$ than RA in genomic activity (activation of a retinoic acid response element), while exhibiting similar non-genomic (activation of ERK kinase) potency $\left(\mathrm{EC}_{50}\right)$ to RA [30].

Several studies had already shown the involvement of RA signaling in amyloid pathology. RA deficiency leads to $A \beta$ accumulation in the cerebral cortex and blood vessels $[18,19]$ and a group of amyloid processing proteins is upregulated by RA, including BACE1 [51], APP [52], ADAM10 [53], IDE, and NEP [24, 53]. Induction of these proteins by RA will be therapeutically advantageous, with the conspicuous exception of BACE1 in which induction could potentially worsen the disease. In this new study, RA, along with a group of synthetic RAR$M$ compounds, upregulated the amyloid processing genes. Of the tested compounds, RAR-Ms DC526, DC528, and DC645 were more effective at inducing Mme, Ide, and Adam10 in both cortical and primary neurons compared to control, with no or weak induction or downregulation of Bace1. DC528 and DC645 induction of Mme was notably stronger compared to RA in both cortical and primary neurons. DC526 and DC645 increased Adam10 in cortical neurons compared to RA. It was also notable that although these RAR-Ms were selected according to their potent genomic and non-genomic biological activities, there was significant variance in the genes they activated; for instance, DC525 reduced the levels of genes such as Mme, which is disadvantageous in the treatment of $\mathrm{AD}$.

RA has neuroprotective properties since it lowers cholesterol levels by upregulating the expression of genes involved in cholesterol homeostasis, such as Abca1 and Abcg1 [56]. These ABC cholesterol transporters play a role in the lipidation of ApoE, the protein involved in the transport of cholesterol to neurons via low density lipoprotein receptors, which promotes the clearance of A $\beta$ [97-99]. The RAR-M compounds were shown to upregulate the expression of Abcal, Abcg1, and Apoe involved in cholesterol regulation and neuroprotection, with DC526, DC528, and DC645 being significantly stronger compared to RA in most cultures. Regulation of cholesterol homeostasis is important for synaptic transmission and neural plasticity [100], and excess cholesterol levels promote the generation of $A \beta$ [101]. 
Other neuroprotective genes investigated included Sodl, the encoded protein known to bind copper and zinc ions and quench free superoxide radical species in the body. There are elevated levels of oxidative stress in AD patients and transgenic mouse models of $\mathrm{AD}[102,103]$ and $\mathrm{A} \beta \mathrm{PP}$ and $\mathrm{A} \beta$ impair mitochondrial import channels and electron transport chain, leading to the generation of free reactive oxygen species [104]. Sodl was notably upregulated by DC526, DC528, DC645, and DC716 compared to the control in both cortical and hippocampal cultures.

The ability of the RAR-Ms to suppress an LPS induced inflammatory reaction was also investigated in the mixed neuronal/glial cultures, adding the RAR$M$ after inflammation was induced for 6 hours. Neuroinflammation has been proposed to play a role in $\mathrm{AD}$ and elevation in inflammatory response and mediators is associated with cognitive decline and loss of neurons in $\mathrm{AD}$ patients and transgenic animal models of AD [105, 106]. Microglia act to clear $\mathrm{A} \beta$ through phagocytosis; however, this interaction activates signaling cascades which, in turn, mediate the release of different pro-inflammatory cytokines (TNF $\alpha$, IL-1 $\beta$, etc.), chemokines (CCL3, CCL5, etc.), and reactive oxygen/nitrogen species which further promotes $A \beta$ plaques $[107,108]$. Each of the RAR-Ms downregulated the expression of multiple genes involved in inflammation whether in cortical or hippocampal cultures such as $\mathrm{Ccl3}, \mathrm{Ccl} 5, \mathrm{Tnf}$, Nos2, and Il-1ß, with DC526, DC528, and DC645 being significantly more effective compared to RA in decreasing these inflammatory markers in most cultures. Surprisingly though, RAR-Ms upregulated Il-12 gene expression. It was reported previously that IL-12 may have anti-inflammatory activity [109]. Moreover, the regulation of this interleukin might depend on choosing the right treatment time, as it can fall and then rise following the induction of inflammation [110].

LPS induced inflammation may also promote neurodegeneration through control of the expression of growth factors. In hippocampal cultures, LPS repressed both $I g f I$ and $I g f 2$ (although markedly inducing $I g f 2$ in cortical cultures reminiscent of the effect of LPS on human microglia [111]). IGF1 and IGF2 modulate the survival of neurons and protect against cytokine mediated death of neurons in human neuronal cultures [111]. IGF1 increases $\alpha$-secretase processing of $A \beta P P$ and decreases $A \beta$ levels [112]. IGF1 and IGF2 have both been proposed as treatments for AD [113-115]. Several of the RAR-Ms upregulated the expression of both IgfI and Igf 2 genes and by increasing endogenous levels of the growth factors, this circumvents the major problem of IGF1 or IGF2 treatment-poor BBB permeability. Small lipophilic ligands for RARs generally cross the BBB [28, 116], while RAR ligands like Am80 [117] and acitretin [118] have demonstrable therapeutic action in $\mathrm{AD}$ mouse models, indicative of their capacity to cross the BBB.

Overall, this study strengthens the argument of decreased RA signaling in early $\mathrm{AD}$ and the subsequent dysregulation of the RA signaling system, which could contribute to the underlying pathogenesis. The earliest consistent change in all models examined was in RA receptors at both RNA and protein level, and these may be earliest changes following the onset of tau and amyloid dysregulation. The many other alterations in genes involved in RA signaling may be secondary and in part compensatory. For instance, the change in RALDH2 may, like CYP26A1 and CYP26B1, be a result of feedback regulation of the RA signaling system, or alternatively may be a response to inflammation. Changes in RBP4, STRA6 and CRBP1, associated with vitamin A's role in metabolic disease [87] may be linked with the metabolic abnormalities that occur in AD [119].

The initial test of the therapeutic potential of RARMs found that DC526, DC528, and DC645 had a strong anti-inflammatory effect downregulating most inflammation genes more effectively than RA. They would be expected to have neuroprotective activity as they induced the expression of both Igfl and SodI. DC526, DC528, and DC645 regulate A $\beta P P$ processing in a beneficial way, inducing Mme and Adam10 to a greater extent than RA and also inducing Ide, but having a lower effect on Bacel than RA. Several other RAR-Ms also had beneficial effects on a more limited number of genes - these were more potent than RA but did not have the broader positive effects of DC526, DC528, and DC645. For example, DC540 and DC527 effectively repressed inflammatory genes but also downregulated Mme and Ide which are important for degrading A $\beta$. Such RARMs may have future potential to be used to target specific pathways.

Of the ligands for RA receptors investigated as $\mathrm{AD}$ therapeutics the most interest has been directed towards bexarotene, an agonist of retinoid X receptors (RXR) which are related to the RARs but with a wider range of action because they heterodimerize with many nuclear receptors including PPAR, thyroid hormone receptor, vitamin D receptors and others, 
including RAR. After the initial promise [55], not all initial findings were replicated [120] but continued research suggests that bexarotene may still have benefit as a therapeutic [121]. An important route of action is the clearance of $A \beta$ by upregulating ApoE levels [55]. Of the RAR-Ms investigated herein, a few significantly upregulated Apoe levels, such as DC525 in cortical neurons and DC528 in hippocampal neurons. However, there are a number of adverse effects including cardiovascular risk due to hypertriglyceridemia [122]. In comparison, the specificity of the RAR-Ms for a single nuclear receptor should reduce side-effects and the variety of therapeutic actions of these drugs to be anti-inflammatory, neuroprotective, and promote the non-amyloidogenic pathway, suggesting promise in the future for treatment of $\mathrm{AD}$ and other neurodegenerative diseases.

\section{ACKNOWLEDGMENTS}

Support was received from BBSRC grant (BB/ P004806/1), Alzheimer's Society grant (AS-PG-14039), ARUK grant (ARUK-PG2017B-11) and NHS Grampian.

Authors' disclosures available online (https:// www.j-alz.com/manuscript-disclosures/19-0931r2).

\section{SUPPLEMENTARY MATERIAL}

The supplementary material is available in the electronic version of this article: https://dx.doi.org/ 10.3233/JAD-190931.

\section{REFERENCES}

[1] Selkoe DJ (2001) Alzheimer's disease: Genes, proteins, and therapy. Physiol Rev 81, 741-766.

[2] Dementia: Fact sheet, Last updated 2017, Accessed on 2017.

[3] Prince M, Comas-Herrera A, Knapp M, Guerchet M, Karagiannidou M (2016) World Alzheimer Report 2016: Improving healthcare for people living with dementia. Coverage, Quality and costs now and in the future. Alzheimer's Disease International, London.

[4] Shearer KD, Stoney PN, Morgan PJ, McCaffery PJ (2012) A vitamin for the brain. Trends Neurosci 35, 733-741.

[5] Mey J, Mccaffery P (2004) Retinoic acid signaling in the nervous system of adult vertebrates. Neuroscientist 10, 409-421.

[6] Silva AJ (2003) Molecular and cellular cognitive studies of the role of synaptic plasticity in memory. J Neurobiol 54, 224-237.

[7] Chiang MY, Misner D, Kempermann G, Schikorski T, Giguère V, Sucov HM, Gage FH, Stevens CF, Evans RM
(1998) An essential role for retinoid receptors RARbeta and RXRgamma in long-term potentiation and depression. Neuron 21, 1353-1361.

[8] Bonnet E, Touyarot K, Alfos S, Pallet V, Higueret P, Abrous DN (2008) Retinoic acid restores adult hippocampal neurogenesis and reverses spatial memory deficit in vitamin A deprived rats. PLoS One 3, e3487.

[9] Aoto J, Nam CI, Poon MM, Ting P, Chen L (2008) Synaptic signaling by all-trans retinoic acid in homeostatic synaptic plasticity. Neuron 60, 308-320.

[10] Corcoran J, Maden M (1999) Nerve growth factor acts via retinoic acid synthesis to stimulate neurite outgrowth. Nat Neurosci 2, 307-308.

[11] Huang X, Zhang H, Zhen J, Dong S, Guo Y, Van HalmLutterodt N, Yuan L (2018) Diminished circulating retinol and elevated $\alpha-\mathrm{TOH} / \mathrm{retinol}$ ratio predict an increased risk of cognitive decline in aging Chinese adults, especially in subjects with ApoE2 or ApoE4 genotype. Aging 10, 4066-4083.

[12] Touyarot K, Bonhomme D, Roux P, Alfos S, Lafenêtre P, Richard E, Higueret P, Pallet V (2013) A mid-life vitamin A supplementation prevents age-related spatial memory deficits and hippocampal neurogenesis alterations through CRABP-I. PLoS One 8, e72101.

[13] Mingaud F, Mormede C, Etchamendy N, Mons N, Niedergang B, Wietrzych M, Pallet V, Jaffard R, Krezel W, Higueret P, Marighetto A (2008) Retinoid hyposignaling contributes to aging-related decline in hippocampal function in short-term/working memory organization and long-term declarative memory encoding in mice. $\mathrm{J} \mathrm{Neu}$ rosci 28, 279-291.

[14] Goodman AB, Pardee AB (2003) Evidence for defective retinoid transport and function in late onset Alzheimer's disease. Proc Natl Acad Sci U S A 100, 2901-2905.

[15] Lee H, Casadesus G, Zhu X, Lee H, Perry G, Smith MA, Gustaw-Rothenberg K, Lerner A (2010) All-trans-retinoic acid as a novel therapeutic strategy for Alzheimer's disease. Expert Rev Neurother 9, 1615-1621.

[16] Ono K, Yoshiike Y, Takashima A, Hasegawa K, Naiki H, Yamada M (2004) Vitamin A exhibits potent antiamyloidogenic and fibril-destabilizing effects in vitro. Exp Neurol 189, 380-392.

[17] Sahin M, Karauzum SB, Perry G, Smith MA, Aliciguzel Y (2005) Retinoic acid isomers protect hippocampal neurons from amyloid-beta induced neurodegeneration. Neurotox Res 7, 243-250.

[18] Husson M, Enderlin V, Delacourte A, Ghenimi N, Alfos S, Pallet V, Higueret P (2006) Retinoic acid normalizes nuclear receptor mediated hypo-expression of proteins involved in beta-amyloid deposits in the cerebral cortex of vitamin A deprived rats. Neurobiol Dis 23, 1-10.

[19] Corcoran JPT, So PL, Maden M (2004) Disruption of the retinoid signalling pathway causes a deposition of amyloid beta in the adult rat brain. Eur J Neurosci 20, 896-902.

[20] Zitnik RJ, Kotloff RM, Latifpour J, Zheng T, Whiting NL, Schwalb J, Elias JA (1994) Retinoic acid inhibition of IL-1-induced IL-6 production by human lung fibroblasts. J Immunol 152, 1419-1427.

[21] Kagechika H, Kawachi E, Fukasawa H, Saito G, Iwanami N, Umemiya H, Hashimoto Y, Shudo K (1997) Inhibition of IL-1-induced IL-6 production by synthetic retinoids. Biochem Biophys Res Commun 231, 243-248.

[22] Tehranian R, Hasanvan H, Iverfeldt K, Post C, Schultzberg M (2001) Early induction of interleukin-6 mRNA in 
the hippocampus and cortex of APPsw transgenic mice Tg2576. Neurosci Lett 301, 54-58.

[23] Dheen ST, Jun Y, Yan Z, Tay SSW, Ling EA (2005) Retinoic acid inhibits expression of TNF- $\alpha$ and iNOS in activated rat microglia. Glia 50, 21-31.

[24] Goncalves MB, Clarke E, Hobbs C, Malmqvist T, Deacon R, Jack J, Corcoran JPT (2013) Amyloid $\beta$ inhibits retinoic acid synthesis exacerbating Alzheimer disease pathology which can be attenuated by an retinoic acid receptor $\alpha$ agonist. Eur J Neurosci 37, 1182-1192.

[25] Kawahara K, Nishi K, Suenobu M, Ohtsuka H, Maeda A, Nagatomo K, Kuniyasu A, Staufenbiel M, Nakagomi M, Shudo K, Nakayama H (2009) Oral administration of synthetic retinoid Am80 (Tamibarotene) decreases brain beta-amyloid peptides in APP23 mice. Biol Pharm Bull 32, 1307-1309.

[26] Katsuki H, Kurimoto E, Takemori S, Kurauchi Y, Hisatsune A, Isohama Y, Izumi Y, Kume T, Shudo K, Akaike A (2009) Retinoic acid receptor stimulation protects midbrain dopaminergic neurons from inflammatory degeneration via BDNF-mediated signaling. J Neurochem 110, 707-718.

[27] Tippmann F, Hundt J, Schneider A, Endres K, Fahrenholz F (2009) Up-regulation of the alpha-secretase ADAM10 by retinoic acid receptors and acitretin. FASEB J 23, 16431654.

[28] Holthoewer D, Endres K, Schuck F, Hiemke C, Schmitt U, Fahrenholz F (2012) Acitretin, an enhancer of alphasecretase expression, crosses the blood-brain barrier and is not eliminated by P-glycoprotein. Neurodegener Dis 10, 224-228.

[29] Endres K, Fahrenholz F, Lotz J, Hiemke C, Teipel S, Lieb K, Tuscher O, Fellgiebel A (2014) Increased CSF APPs- levels in patients with Alzheimer disease treated with acitretin. Neurology 83, 1930-1935.

[30] Khatib T, Marini P, Nunna S, Chisholm DR, Whiting A, Redfern C, Greig IR, McCaffery P (2019) Genomic and non-genomic pathways are both crucial for peak induction of neurite outgrowth by retinoids. Cell Commun Signal 17, 1-16.

[31] Haffez H, Chisholm DR, Valentine R, Pohl E, Redfern C, Whiting A (2017) The molecular basis of the interactions between synthetic retinoic acid analogues and the retinoic acid receptors. Med Chem Comm 8, 578-592.

[32] Clemens G, Flower KR, Gardner P, Henderson AP, Knowles JP, Marder TB, Whiting A, Przyborski S (2013) Design and biological evaluation of synthetic retinoids: probing length vs. stability vs. activity. Mol Biosyst $\mathbf{9}$, 3124-3134.

[33] Christie VB, Barnard JH, Batsanov AS, Bridgens CE, Cartmell EB, Collings JC, Maltman DJ, Redfern CPF, Marder TB, Przyborski S, Whiting A (2008) Synthesis and evaluation of synthetic retinoid derivatives as inducers of stem cell differentiation. Org Biomol Chem 6, 3497-3507.

[34] Zhou G-L, Tams DM, Marder TB, Valentine R, Whiting A, Przyborski SA (2013) Synthesis and applications of 2,4-disubstituted thiazole derivatives as small molecule modulators of cellular development. Org Biomol Chem 11, 2323-2334.

[35] Haffez H, Chisholm DR, Tatum NJ, Valentine R, Redfern C, Pohl E, Whiting A, Przyborski S (2018) Probing biological activity through structural modelling of ligand-receptor interactions of 2,4-disubstituted thiazole retinoids. Bioorg Med Chem 26, 1560-1572.
[36] Gluyas JBG, Burschka C, Dörrich S, Vallet J, Gronemeyer H, Tacke R (2012) Disila-analogues of the synthetic retinoids EC23 and TTNN: synthesis, structure and biological evaluation. Org Biomol Chem 10, 6914-6929.

[37] Whiting A, Valentine R, Chisholm DR, McCaffery P, Greig IR, Khatib T (2019) Synthetic retinoids for use in rar activation. Patent No. GB1903242.4

[38] Platt B, Drever B, Koss D, Stoppelkamp S, Jyoti A, Plano A, Utan A, Merrick G, Ryan D, Melis V, Wan H, Mingarelli M, Porcu E, Scrocchi L, Welch A, Riedel G (2011) Abnormal cognition, sleep, EEG and brain metabolism in a novel knock-in Alzheimer mouse, PLB1. PLoS One 6, e27068.

[39] Plucińska K, Crouch B, Yeap JM, Stoppelkamp S, Riedel G, Platt B (2018) Histological and behavioral phenotypes of a novel mutated APP knock-in mouse. J Alzheimers Dis 65, 165-180.

[40] Koss DJ, Robinson L, Drever BD, Plucińska K, Stoppelkamp S, Veselcic P, Riedel G, Platt B (2016) Mutant tau knock-in mice display frontotemporal dementia relevant behaviour and histopathology. Neurobiol Dis 91, 105-123.

[41] Plucińska K, Crouch B, Koss D, Robinson L, Siebrecht M, Riedel G, Platt B (2014) Knock-in of human BACE1 cleaves murine APP and reiterates Alzheimer-like phenotypes. J Neurosci 34, 10710-10728.

[42] Snyder JS, Choe JS, Clifford MA, Jeurling SI, Hurley P, Brown A, Kamhi JF, Cameron HA (2009) Adult-born hippocampal neurons are more numerous, faster maturing, and more involved in behavior in rats than in mice. J Neurosci 29, 14484-14495.

[43] Ye J, Coulouris G, Zaretskaya I, Cutcutache I, Rozen S, Madden TL (2012) Primer-BLAST: A tool to design target-specific primers for polymerase chain reaction. BMC Bioinformatics 13, 134.

[44] Xie F, Xiao P, Chen D, Xu L, Zhang B (2012) miRDeepFinder: A miRNA analysis tool for deep sequencing of plant small RNAs. Plant Mol Biol 80, 75-84.

[45] Aldridge GM, Podrebarac DM, Greenough WT, Weiler IJ (2008) The use of total protein stains as loading controls: an alternative to high-abundance single protein controls in semi-quantitative immunoblotting. Neurosci Methods 172, 250-254.

[46] Romero-Calvo I, Ocón B, Martínez-Moya P, Suárez MD, Zarzuelo A, Martínez-Augustin O, de Medina FS (2010) Reversible Ponceau staining as a loading control alternative to actin in Western blots. Anal Biochem 401, 318-320.

[47] Simões AE, Pereira DM, Amaral JD, Nunes AF, Gomes SE, Rodrigues PM, Lo AC, D'Hooge R, Steer CJ, Thibodeau SN, Borralho PM, Rodrigues CM (2013) Efficient recovery of proteins from multiple source samples after trizol ${ }^{\circledR}$ or trizol ${ }^{\circledR}$ LS RNA extraction and long-term storage. BMC Genomics 14, 181.

[48] Sirois I, Raymond M-A, Brassard N, Cailhier J-F, Fedjaev M, Hamelin K, Londono I, Bendayan M, Pshezhetsky A V, Hébert M-J (2011) Caspase-3-dependent export of TCTP: a novel pathway for antiapoptotic intercellular communication. Cell Death Differ 18, 549-562.

[49] Hernandez-Rapp J, Rainone S, Goupil C, Dorval V, Smith PY, Saint-Pierre M, Vallée M, Planel E, Droit A, Calon F, Cicchetti F, Hébert SS (2016) microRNA-132/212 deficiency enhances $A \beta$ production and senile plaque deposition in Alzheimer's disease triple transgenic mice. Sci Rep 6, 30953. 
[50] Li R, Shen Y (2013) An old method facing a new challenge: Re-visiting housekeeping proteins as internal reference control for neuroscience research. Life Sci 92, 747-751.

[51] Satoh J, Kuroda Y (2000) Amyloid precursor protein betasecretase (BACE) mRNA expression in human neural cell lines following induction of neuronal differentiation and exposure to cytokines and growth factors. Neuropathology 20, 289-296.

[52] Yang Y, Quitschke WW, Brewer GJ (1998) Upregulation of amyloid precursor protein gene promoter in rat primary hippocampal neurons by phorbol ester, IL-1 and retinoic acid, but not by reactive oxygen species. Mol Brain Res 60, 40-49.

[53] Endres K, Postina R, Schroeder A, Mueller U, Fahrenholz F (2005) Shedding of the amyloid precursor proteinlike protein APLP2 by disintegrin-metalloproteinases: Retinoic acid-induced upregulation of substrate and proteinase ADAM10 during neuronal cell differentiation. FEBS J 272, 5808-5820.

[54] Wang R, Chen S, Liu Y, Diao S, Xue Y, You X, Park EA, Liao F-F (2015) All-trans-retinoic acid reduces BACE1 expression under inflammatory conditions via modulation of nuclear factor $\kappa \mathrm{B}(\mathrm{NF} \kappa \mathrm{B})$ signaling. J Biol Chem 290, 22532-22542.

[55] Cramer PE, Cirrito JR, Wesson DW, Lee CYD, Karlo JC, Zinn AE, Casali BT, Restivo JL, Goebel WD, James MJ, Brunden KR, Wilson DA, Landreth GE (2012) ApoEdirected therapeutics rapidly clear -amyloid and reverse deficits in AD mouse models. Science 335, 1503-1506.

[56] Chen J, Costa LG, Guizzetti M (2011) Retinoic acid isomers up-regulate ATP binding cassette A1 and G1 and cholesterol efflux in rat astrocytes: implications for their therapeutic and teratogenic effects. J Pharmacol Exp Ther 338, 870-878.

[57] Ahlemeyer B, Bauerbach E, Plath M, Steuber M, Heers C, Tegtmeier F, Krieglstein J (2001) Retinoic acid reduces apoptosis and oxidative stress by preservation of SOD protein level. Free Radic Biol Med 30, 1067-1077.

[58] van Neerven S, Nemes A, Imholz P, Regen T, Denecke B, Johann S, Beyer C, Hanisch U-K, Mey J (2010) Inflammatory cytokine release of astrocytes in vitro is reduced by all-trans retinoic acid. J Neuroimmunol 229, 169-179.

[59] van Neerven S, Regen T, Wolf D, Nemes A, Johann S, Beyer C, Hanisch U-K, Mey J (2010) Inflammatory chemokine release of astrocytes in vitro is reduced by all-trans retinoic acid. J Neurochem 114, 1511-1526.

[60] King A (2018) The search for better animal models of Alzheimer's disease. Nature 559, S13-S15.

[61] Sodhi RK, Singh N (2014) Retinoids as potential targets for Alzheimer's disease. Pharmacol Biochem Behav 120, 117-123.

[62] Etchamendy N, Enderlin V, Marighetto A, Pallet V, Higueret P, Jaffard R (2003) Vitamin A deficiency and relational memory deficit in adult mice: Relationships with changes in brain retinoid signalling. Behav Brain Res 145, 37-49.

[63] Balmer JE, Blomhoff R (2002) Gene expression regulation by retinoic acid. J Lipid Res $\mathbf{4 3}, 1773-1808$.

[64] Lane MA, Bailey SJ (2005) Role of retinoid signalling in the adult brain. Prog Neurobiol 75, 275-293.

[65] Hellmann-Regen J, Kronenberg G, Uhlemann R, Freyer D, Endres M, Gertz K (2013) Accelerated degradation of retinoic acid by activated microglia. J. Neuroimmunol 256, $1-6$.
[66] Etchamendy N, Enderlin V, Marighetto A, Vouimba RM, Pallet V, Jaffard R, Higueret P (2001) Alleviation of a selective age-related relational memory deficit in mice by pharmacologically induced normalization of brain retinoid signaling. J Neurosci 21, 6423-6429.

[67] Xia X, Jiang Q, McDermott J, Han JJ (2018) Aging and Alzheimer's disease: Comparison and associations from molecular to system level. Aging Cell 17, e12802.

[68] Nativio R, Donahue G, Berson A, Lan Y, Amlie-Wolf A, Tuzer F, Toledo JB, Gosai SJ, Gregory BD, Torres C, Trojanowski JQ, Wang L-S, Johnson FB, Bonini NM, Berger SL (2018) Dysregulation of the epigenetic landscape of normal aging in Alzheimer's disease. Nat Neurosci 21, 497-505.

[69] Zhu B-L, Long Y, Luo W, Yan Z, Lai Y-J, Zhao L-G, Zhou W-H, Wang Y-J, Shen L-L, Liu L, Deng X-J, Wang X-F, Sun F, Chen G-J (2019) MMP13 inhibition rescues cognitive decline in Alzheimer transgenic mice via BACE1 regulation. Brain 142, 176-192.

[70] Ocampo A, Reddy P, Martinez-Redondo P, PlateroLuengo A, Hatanaka F, Hishida T, Li M, Lam D, Kurita M, Beyret E, Araoka T, Vazquez-Ferrer E, Donoso D, Roman JL, Xu J, Rodriguez Esteban C, Nuñez G, Nuñez Delicado E, Campistol JM, Guillen I, Guillen P, Izpisua Belmonte JC (2016) In vivo amelioration of ageassociated hallmarks by partial reprogramming. Cell 167, 1719-1733.e12.

[71] Urvalek A, Laursen KB, Gudas LJ (2014) The roles of retinoic acid and retinoic acid receptors in inducing epigenetic changes. Subcell Biochem 70, 129-149.

[72] Connor MJ, Sidell N (1997) Retinoic acid synthesis in normal and Alzheimer diseased brain and human neural cells. Mol Chem Neuropathol 30, 239-252.

[73] Mey J, Morassutti DJ, Brook G, Liu RH, Zhang YP, Koopmans G, McCaffery P (2005) Retinoic acid synthesis by a population of NG2-positive cells in the injured spinal cord. Eur J Neurosci 21, 1555-1568.

[74] Kern J, Schrage K, Koopmans GC, Joosten EA, McCaffery P, Mey J (2007) Characterization of retinaldehyde dehydrogenase-2 induction in NG2-positive glia after spinal cord contusion injury. Int J Dev Neurosci 25, 7-16.

[75] Maier T, Güell M, Serrano L (2009) Correlation of mRNA and protein in complex biological samples. FEBS Lett 583, 3966-3973.

[76] de Sousa Abreu R, Penalva L, Marcotte E, Vogel C (2014) Global signatures of protein and mRNA expression levels. Mol Biosyst 5, 1512-1526.

[77] Kreżel W, Kastner P, Chambon P (1999) Differential expression of retinoid receptors in the adult mouse central nervous system. Neuroscience 89, 1291-1300.

[78] Ray WJ, Bain G, Yao M, Gottlieb DI (1997) CYP26, a novel mammalian cytochrome $\mathrm{P} 450$, is induced by retinoic acid and defines a new family. J Biol Chem 272, 1870218708.

[79] de The H, Marchio A, Tiollais P, Dejean A (1989) Differential expression and ligand regulation of the retinoic acid receptor alpha and beta genes. EMBO J 8, 429-433.

[80] Loudig O, Babichuk C, White J, Abu-Abed S, Mueller C, Petkovich M (2000) Cytochrome P450RAI(CYP26) promoter: a distinct composite retinoic acid response element underlies the complex regulation of retinoic acid metabolism. Mol Endocrinol 14, 1483-1497.

[81] de The H, Vivanco-Ruiz MM, Tiollais P, Stunnenberg H, Dejean A (1990) Identification of a retinoic acid respon- 
sive element in the retinoic acid receptor beta gene. Nature 343, 177-180.

[82] Goodman DS (1980) Plasma retinol-binding protein. Ann N Y Acad Sci 348, 378-390.

[83] Mody N, Agouni A, Mcilroy GD, Platt B, Delibegovic M (2011) Susceptibility to diet-induced obesity and glucose intolerance in the APP SWE/PSEN1 A246E mouse model of Alzheimer's disease is associated with increased brain levels of protein tyrosine phosphatase 1B (PTP1B) and retinol-binding protein 4 (RBP4), and bas. Diabetologia 54, 2143-2151.

[84] Plucińska K, Dekeryte R, Koss D, Shearer K, Mody N, Whitfield PD, Doherty MK, Mingarelli M, Welch A, Riedel G, Delibegovic M, Platt B (2016) Neuronal human BACE1 knockin induces systemic diabetes in mice. Diabetologia 59, 1513-1523.

[85] Maury CPJ, Teppo AM (1987) Immunodetection of protein composition in cerebral amyloid extracts in Alzheimer's disease: Enrichment of retinol-binding protein. J Neurol Sci 80, 221-228.

[86] Jung SM, Lee K, Lee JW, Namkoong H, Kim HK, Kim S, Na HR, Ha S-A, Kim J-R, Ko J, Kim JW (2008) Both plasma retinol-binding protein and haptoglobin precursor allele 1 in CSF: Candidate biomarkers for the progression of normal to mild cognitive impairment to Alzheimer's disease. Neurosci Lett 436, 153-157.

[87] Blaner WS (2019) Vitamin A signaling and homeostasis in obesity, diabetes, and metabolic disorders. Pharmacol Ther 197, 153-178.

[88] Noy N (2016) Vitamin A transport and cell signaling by the retinol-binding protein receptor STRA6. In The Biochemistry of Retinoid Signaling II, AssonBatres MA, Rochette-Egly C, eds. Springer, Dordrecht, pp. 77-93.

[89] Berry DC, Jin H, Majumdar A, Noy N (2011) Signaling by vitamin $\mathrm{A}$ and retinol-binding protein regulates gene expression to inhibit insulin responses. Proc Natl Acad Sci U S A 108, 4340-4345.

[90] Kane MA, Folias AE, Pingitore A, Perri M, Krois CR, Ryu JY, Cione E, Napoli JL (2011) CrbpI modulates glucose homeostasis and pancreas 9-cis-retinoic acid concentrations. Mol Cell Biol 31, 3277-3285.

[91] Velayudhan L, Killick R, Hye A, Kinsey A, Güntert A, Lynham S, Ward M, Leung R, Lourdusamy A, To AWM, Powell J, Lovestone S (2012) Plasma transthyretin as a candidate marker for Alzheimer's disease. J Alzheimers Dis 28, 369-375.

[92] Serot J-M, Christmann D, Dubost T, Couturier M (1997) Cerebrospinal fluid transthyretin: aging and late onset Alzheimer's disease. J Neurol Neurosurg Psychiatry 63, 506-508.

[93] Das B, Dasgupta S, Ray S (2019) Potential therapeutic roles of retinoids for prevention of neuroinflammation and neurodegeneration in Alzheimer's disease. Neural Regen Res 14, 1880-1892.

[94] Cummings JL, Zhong K, Kinney JW, Heaney C, MollTudla J, Joshi A, Pontecorvo M, Devous M, Tang A, Bena J (2016) Double-blind, placebo-controlled, proofof-concept trial of bexarotene in moderate Alzheimer's disease. Alzheimers Res Ther $\mathbf{8}, 4$.

[95] Gundersen TE, Blomhoff R (2001) Qualitative and quantitative liquid chromatographic determination of natural retinoids in biological samples. $J$ Chromatogr A 935, 1343.
[96] Barua AB, Furr HC (1998) Properties of retinoids. In Retinoid Protocols, Redfern CPF, ed. Humana Press, Totowa, NJ, pp. 3-28.

[97] Wahrle SE, Jiang H, Parsadanian M, Kim J, Li A, Knoten A, Jain S, Hirsch-reinshagen V, Wellington CL, Bales KR, Paul SM, Holtzman DM (2008) Overexpression of ABCA1 reduces amyloid deposition in the PDAPP mouse model of Alzheimer disease. J Clin Invest 118, 671-682.

[98] Jiang Q, Lee CYD, Mandrekar S, Wilkinson B, Cramer P, Zelcer N, Mann K, Lamb B, Willson TM, Collins JL, Richardson JC, Smith JD, Comery TA, Riddell D, Holtzman DM, Tontonoz P, Landreth GE (2008) ApoE promotes the proteolytic degradation of A $\beta$. Neuron $\mathbf{5 8}$, 681-693.

[99] Liu C-C, Kanekiyo T, Xu H, Bu G (2013) Apolipoprotein $\mathrm{E}$ and Alzheimer disease: risk, mechanisms and therapy. Nat Rev Neurol 9, 106-118.

[100] Wahrle SE, Jiang H, Parsadanian M, Hartman RE, Bales KR, Paul SM, Holtzman DM (2005) Deletion of Abca1 increases $\mathrm{A} \beta$ deposition in the PDAPP transgenic mouse model of Alzheimer disease. J Biol Chem 280, 4323643242.

[101] Runz H, Rietdorf J, Tomic I, de Bernard M, Beyreuther K, Pepperkok R, Hartmann T (2002) Inhibition of intracellular cholesterol transport alters presenilin localization and amyloid precursor protein processing in neuronal cells. J Neurosci 22, 1679-1689.

[102] Nunomura A, Castellani RJ, Zhu X, Moreira PI, Perry G, Smith MA (2006) Involvement of oxidative stress in Alzheimer disease. J Neuropathol Exp Neurol 65, 631641.

[103] Praticò D, Uryu K, Leight S, Trojanoswki JQ, Lee VMY (2001) Increased lipid peroxidation precedes amyloid plaque formation in an animal model of Alzheimer amyloidosis. J Neurosci 21, 4183-4187.

[104] Manczak M, Anekonda TS, Henson E, Park BS, Quinn J, Reddy PH (2006) Mitochondria are a direct site of $A \beta$ accumulation in Alzheimer's disease neurons: Implications for free radical generation and oxidative damage in disease progression. Hum Mol Genet 15, 1437-1449.

[105] Johnston H, Boutin H, Allan SM (2011) Assessing the contribution of inflammation in models of Alzheimer's disease. Biochem Soc Trans 39, 886-890.

[106] Regen F, Hellmann-Regen J, Costantini E, Reale M (2017) Neuroinflammation and Alzheimer's disease: implications for microglial activation. Curr Alzheimer Res 14, 11401148.

[107] Weitz TM, Town T (2012) Microglia in Alzheimer's disease: It's all about context. Int J Alzheimers Dis 2012, 314185.

[108] Bamberger ME, Harris ME, McDonald DR, Husemann J, Landreth GE (2003) A cell surface receptor complex for fibrillar beta-amyloid mediates microglial activation. J Neurosci 23, 2665-2674.

[109] Chang HD, Radbruch A (2007) The pro- and antiinflammatory potential of interleukin-12. Ann N Y Acad Sci 1109, 40-46.

[110] Desmet SJ, De Bosscher K (2017) Glucocorticoid receptors: finding the middle ground. J Clin Invest 127, 1136-1145.

[111] Suh H-S, Zhao M-L, Derico L, Choi N, Lee SC (2013) Insulin-like growth factor 1 and 2 (IGF1, IGF2) expression in human microglia: differential regulation by inflammatory mediators. J Neuroinflammation 10, 37. 
[112] Jacobsen KT, Adlerz L, Multhaup G, Iverfeldt K (2010) Insulin-like growth factor-1 (IGF-1)-induced processing of amyloid-beta precursor protein (APP) and APP-like protein 2 is mediated by different metalloproteinases. J Biol Chem 285, 10223-10231.

[113] George C, Gontier G, Lacube P, François J-C, Holzenberger M, Ä̈d S (2017) The Alzheimer's disease transcriptome mimics the neuroprotective signature of IGF-1 receptor-deficient neurons. Brain 140, 2012-2027.

[114] Pardo M, Cheng Y, Sitbon YH, Lowell JA, Grieco SF, Worthen RJ, Desse S, Barreda-Diaz A (2019) Insulin growth factor 2 (IGF2) as an emergent target in psychiatric and neurological disorders. Neurosci Res 149, 1-13.

[115] Tanokashira D, Fukuokaya W, Taguchi A (2019) Involvement of insulin receptor substrates in cognitive impairment and Alzheimer's disease. Neural Regen Res 14, 13301334.

[116] Jarvis CI, Goncalves MB, Clarke E, Dogruel M, Kalindjian SB, Thomas SA, Maden M, Corcoran JPT (2010) Retinoic acid receptor- $\alpha$ signalling antagonizes both intracellular and extracellular amyloid- $\beta$ production and prevents neuronal cell death caused by amyloid- $\beta$. Eur J Neurosci 32, 1246-1255.

[117] Fukasawa H, Nakagomi M, Yamagata N, Katsuki H, Kawahara K, Kitaoka K, Miki T, Shudo K (2012) Tamibarotene: A candidate retinoid drug for Alzheimer's disease. Biol Pharm Bull 35, 1206-1212.
[118] dos Santos Guilherme M, Stoye NM, Rose-John S, Garbers C, Fellgiebel A, Endres K (2019) The synthetic retinoid acitretin increases IL-6 in the central nervous system of Alzheimer disease model mice and human patients. Front Aging Neurosci 11, 182.

[119] Dekeryte R, Hull C, Plucińska K, Khan S, Kamli-Salino S, Mody N, Morrice N, McLaughlin C, Gault V, Platt B, Delibegovic M (2019) Effects of Liraglutide and Fenretinide treatments on the diabetic phenotype of neuronal human BACE1 knock-in mice. Biochem Pharmacol 166, 222-230.

[120] Landreth GE, Cramer PE, Lakner MM, Cirrito JR, Wesson DW, Brunden KR, Wilson DA (2013) Response to Comments on "ApoE-directed therapeutics rapidly clear $\beta$-amyloid and reverse deficits in AD mouse models." Science 340, 924-g.

[121] Casali BT, Reed-Geaghan EG, Landreth GE (2018) Nuclear receptor agonist-driven modification of inflammation and amyloid pathology enhances and sustains cognitive improvements in a mouse model of Alzheimer's disease. J Neuroinflammation 15, 43.

[122] Maminakis C, Whitman AC, Islam N (2018) Bexaroteneinduced hypertriglyceridemia: a case report. Case Rep Oncol 11, 234-238. 